\title{
Corporate Tax Incentives and Capital Structure: New Evidence from UK Firm-Level Tax Returns
}

\author{
Michael P. Devereux ${ }^{1}$, Giorgia Maffini², Jing Xing ${ }^{3}$
}

\section{Acknowledgement}

Michael Devereux and Jing Xing gratefully acknowledge financial support from the Economic and Social Research Council (ES/L000016/1). Giorgia Maffini gratefully acknowledges financial support from the Leverhulme Trust (ECF-2013-323) and the University of Oxford John Fell OUP Research Fund. We are grateful to HM Revenue and Customs (HMRC) for allowing us access to confidential tax return data in the HMRC Data Lab, and in particular to Daniele Bega, Manpreet Khera, Lucy Nicholson, Yee-Wan Yau and all the Data Lab staff. The following disclaimer applies: "This work contains statistical data from HMRC which is Crown Copyright. The research datasets used may not exactly reproduce HMRC aggregates. The use of HMRC statistical data in this work does not imply the endorsement of HMRC in relation to the interpretation or analysis of the information." We are grateful to Stephen Bond, Raj Chetty, Dhammika Dharmapala, Clemens Fuest, Lilian Mills, Michelle Hanlon, and participants at the NBER Summer Institute, Oxford University Centre for Business Taxation 2014 Annual Symposium, the ZEW seminar series, the Austin Tax Readings Group at the University of Texas at Austin, the 27th Australasian Banking and Finance Conference, the European Finance Association 2015 Annual Meeting, the International Institute of Public Finance 2015 Congress for helpful comments. We are grateful to Strahil Lepoev for his excellent research assistance.

\footnotetext{
${ }^{1}$ Oxford University Centre for Business Taxation, Saïd Business School, University of Oxford. Email: michael.devereux @sbs.ox.ac.uk.

2 Oxford University Centre for Business Taxation, Saïd Business School, University of Oxford; Dondena Centre for Research on Social Dynamics and Public Policy, Bocconi University; and the OECD. Email: giorgia.maffini@oecd.org.

${ }^{3}$ Department of Finance, Antai College of Economics and Management, Shanghai Jiao Tong University. Email: jing.xing@sjtu.edu.cn. Corresponding author. Address: Office 1308, 1954 Huashan Road, Shanghai Jiao Tong University, Shanghai, 200030, P. R. China. Phone: +86-2152301040.
} 


\title{
Corporate Tax Incentives and Capital Structure: New Evidence from UK Firm-Level Tax Returns
}

\begin{abstract}
We investigate how companies' capital structure is affected by corporate income taxes using confidential company-level tax returns for a large sample of UK firms. Exploiting variation in companies' marginal tax rates, we find a positive and substantial long-run tax effect on leverage. Leverage responds more to decreases in the marginal tax rate, and it responds to changes in the marginal rather than the average tax rate. Most importantly, we find that the marginal tax rate based on tax returns has greater explanatory power for companies' leverage than the marginal tax rate based on financial statements. Our study suggests that errors in the measurement for tax incentives using financial statements could lead to underestimation of the tax effects on capital structure.
\end{abstract}

Key words: corporate taxation, capital structure, tax returns

JEL category: G3, H2 


\section{Introduction}

Corporation taxes typically permit a deduction for interest payments but not the opportunity cost of equity finance. They therefore create an incentive to use debt rather than equity finance. To test the effects of tax on capital structure, companies' tax returns are a more accurate tool than financial statements as they indicate a company's tax position more precisely. Nonetheless, few studies have used company-level corporate tax returns as such data are usually confidential. The literature has instead largely relied on accounting financial statements to infer companies' tax positions, or simply used the statutory corporate income tax rate as a proxy for the true tax incentives to use debt. What would be the estimated tax effects on capital structure if we can measure the tax incentives for borrowing based on actual corporate tax returns? Moreover, would errors in the measurement for tax incentives to borrow, in the absence of tax returns, lead to a biased estimate for the tax effect on capital structure? Our study investigates these two issues by comparing the effects on capital structure of two versions of the marginal tax rate: one based on confidential corporate tax returns and one based on financial statements for a same sample of UK companies.

Our study reduces errors in the measurement of tax incentives for using debt in the following ways. Firstly and most importantly, we use company-level confidential corporate tax returns, which are rarely used in previous studies. For a number of reasons, such as earnings management and different requirements for tax and financial reporting, there could be substantial differences between the tax charge in the financial statement and the current tax liability of the company reported to the tax authority. Relative to accounting data from financing statements, the tax return data allow us to measure more precisely the tax incentives for companies to borrow. This improvement in data quality is meaningful-despite the theoretical prediction for a positive link between the marginal tax rate and leverage (Modigliani 
and Miller, 1963), researchers often find it difficult to identify this association empirically. Myers (1984) calls this phenomenon "the capital structure puzzle" and challenges researchers to show that capital structure is affected by taxes as the trade-off theory predicts. Although recent studies (for example, Barclay, Heitzman, and Smith, 2013; Heider and Ljungqvist, 2015; Doidge and Dyck, 2015) are more successful in identifying the tax effects, it remains a question whether measurement errors in tax incentives lead to underestimation of the true tax effect on corporate leverage. Having access to both tax returns and financial statements for the same company, we are able to address this issue directly.

Secondly, we match companies' marginal tax rates based on tax returns with leverage ratios based on financial statements using the same consolidation rule. In contrast, most existing studies of large public companies match companies' worldwide consolidated leverage ratios with the tax rates of the jurisdictions where the headquarters are located. However, as far as multinational companies borrow in different countries, their aggregate borrowing should depend on tax rates in those different countries (Desai et al., 2004; Huizinga et al., 2008; Arena and Roper, 2010). Our data is free of such measurement errors due to data mismatch, since we exploit only unconsolidated data of UK companies - on taxation from tax returns and on other variables from unconsolidated financial accounts.

In our study, variation in companies' marginal tax rates arises due to both the largely progressive corporation tax rate schedule and a number of tax reforms in the UK. Kinks in the UK marginal tax rate schedule, where there are jumps in the marginal tax rate, are significant. For example, at the $£ 300,000$ kink in the tax rate schedule, the marginal tax rate has typically jumped by 12 to 13 percentage points. Among the several kinks in the rate schedule, we also consider one that is more often investigated in the literature - the effective marginal tax rate for interest deduction is lower for a company with taxable losses than that for a company with positive taxable profits even if the statutory tax rate is flat (Graham, 1996a, 1996b). 
During our sample period, there were also a few tax reforms which create additional variation in companies' marginal tax rates, although the magnitude of these tax rate changes is often small. ${ }^{1}$

The main findings of our study are as follows. Based on calculating the marginal tax rate from tax returns matched with financial statement variables, we estimate that in the long run a one percentage point rise in the corporation tax rate would increase the leverage ratio of private companies by around 1 percentage point (our central estimates range from 0.76 to 1.40 , depending on the instruments used). This result suggests that our sample firms are strongly responsive to changes in tax incentives for borrowing. Interestingly, for the same set of companies, we find a much smaller and insignificant estimate for the tax effects on capital structure when we measure tax incentives to borrow based on companies' financial statements. We also find substantial book-tax differences for companies in our sample. These results suggest that the large measurement errors in the tax incentives in the absence of tax returns are likely to lead to underestimation of the true tax effects on corporate leverage.

We find that firms in our study close about $24 \%$ of the gap between their actual leverage ratio and the targeted level each year, close to the adjustment speed estimated by Lemmon et al. (2008) using a similar estimation method. We find some asymmetric tax effect on leverage for private firms in our sample-they respond more to a decrease in the tax incentive than to an increase in the tax incentive. The strong tax effect on leverage is found both among UK domestic stand-alone companies and those belong to a multinational company group. Moreover, we investigate whether companies adjust their capital structure with respect to changes in the theoretically correct marginal tax rate or the average tax rate, which may be more

\footnotetext{
${ }^{1}$ The standard corporate income tax rate was cut from $30 \%$ to $28 \%$ in 2008 ; a $0 \%-10 \%$ starting rate was applied to profits below $£ 10,000$ during fiscal years $2001-2005$; and for small UK companies, the corporate income tax rate was cut from $21 \%$ to $20 \%$ in 1999 , and to $19 \%$ in 2002 . It was then increased to $20 \%$ in 2007 and to $21 \%$ in 2008 . For a more detailed description of the changes in the UK tax system, see Maffini et el. (2016).
} 
salient. By running a horse-race between the two tax rates, we find that firms in our sample only respond to changes in the marginal tax rate. Taken together, our findings are strongly consistent with the trade-off theory of capital structure.

It is worth noting that the purpose of our study is to estimate the tax effects on capital structure using the marginal tax rate based on actual firm-level tax returns, and to understand whether measurement errors in the marginal tax rate based on financial statements of the same firm would materially affect the estimated tax effects on its capital structure choice. Our purpose is not to compare our estimated tax effects on capital structure with those found in previous studies. To achieve meaningful comparison with previous studies, we would need to use similar data (such as data provided by Compustat), focus on a similar group of countries, and use similar econometric specifications and estimation methods. Differences in these dimensions will lead to different results as surveyed by Feld et al. (2013). Nonetheless, given that the discrepancy between tax and financial reporting is a common phenomenon, our study sheds some light on possible outcomes when tax return data can be matched with accounting data used by previous studies.

The rest of the paper is structured as follows. Section 2 briefly review existing studies using tax returns to investigate the tax effects on leverage decisions. In Section 3, we develop a simple theoretical model to illustrate how firms choose leverage when the corporate tax rate schedule contains more than one marginal rate. Section 4 describes our empirical model. Section 5 describes the data and sample selection. Section 6 reports our benchmark estimation results. Section 7 discuss whether our measure of the marginal tax rate better captures the tax incentive to use debt, relative to the marginal tax rate based on publicly available financial statements and the more salient average effective tax rate. Section 8 concludes. 


\section{Literature review}

There has been a large body of empirical studies analyzing the effects of the corporate tax system on firms' capital structure. Graham (2003) provides a survey of literature on this topic. More recent studies, however, are more successful in identifying the tax effects. Using changes in the top corporate income tax rate across OECD countries during 1981-2009, Faccio and Xu (2015) find that corporate leverage increases on average by $0.41 \%$ when the corporate income tax rate increases by 1\%. Barclay, Heitzman, and Smith (2013) find that leverage ratios of taxable real estate firms are higher than their nontaxable counterparts. Heider and Ljungqvist (2015) use variation in state-level corporate income tax rates in the United States and in their benchmark estimations, one percentage point increase in the state-level corporate income tax rate is associated with 0.38 percentage point increase in corporate leverage. Doidge and Dyck (2015) investigate the effects on corporate policies when corporate tax was imposed on Canadian trusts in 2006, and find that these affected trusts increased leverage following the policy change. On the other hand, using long time series, Graham, Leary, and Roberts (2014) find little statistical association between the statutory corporate tax rates and aggregate leverage of US unregulated industrial firms during 1925-2010. ${ }^{2}$

The literature varies widely in terms of how to measure tax incentives for borrowing. As pointed out by Feld et al. (2013), the choice of tax incentive measures significantly affects the estimated tax impact on leverage. Some studies measure tax incentives using the top statutory corporate income tax rate (for example, Faccio and $\mathrm{Xu}, 2015)$. Nonetheless, the top statutory marginal tax rate is likely to be an inaccurate indicator of the true tax incentive for using debt, especially if the tax rate schedule is not flat. It is also well known that firms in the tax exhaustion position face a lower marginal tax rate than the statutory rate. Graham (1996a, 1996b)

\footnotetext{
${ }^{2}$ While Graham, Leary, and Roberts (2014) find no link between aggregate leverage and corporate tax rates, they find a positive association between corporate tax rates and the choice between debt and preferred equity.
} 
proposes the use of the simulated marginal tax rate which captures the different tax incentives for borrowing for loss-making firms. There are many advantages of using the more sophisticated simulated marginal tax rate. Nonetheless, if the calculation of the simulated marginal tax rate is based on financial statements, measurement errors will still occur (Barclay, Heitzman, and Smith, 2013) and they could be potentially large due to the book-tax differences-firms' taxable income reported in financial statements is usually different from taxable income reported to tax authorities. Book-tax differences arise due to different requirements for financial and tax reporting as well as earnings management. A large book-tax difference has also been regarded in the literature as an indicator of tax aggressiveness. Manzon and Plesko (2001) and Desai (2003) report that since the early 1990s, the gap between book income and taxable income for US public firms has been increasing, likely due to increasing tax sheltering activities.

As the divergence between book and taxable income increases, it is thus interesting to investigate whether using tax returns would affect the estimated tax effects on corporate leverage. To investigate this issue requires access to both tax returns and financial statements, which explain the paucity of studies that have attempted to do so. In fact, only a few papers have used actual tax return data and within the few exceptions, aggregated tax returns over companies rather than company-level tax returns are more often used (Gordon and Lee, 2001; Dwenger and Stainer, 2014; Longstaff and Strebulaev, 2014) largely due to confidentiality restrictions. ${ }^{3}$

One relevant study is Graham and Mills (2008) who simulate the effective marginal tax rates using both tax return data and financial statements for a sample of US public companies during the period 1998-2000. Graham and Mills (2008) find a positive correlation between the two marginal tax rates and the simulated marginal tax rate based on financial statements has a stronger explanatory power for firms' leverage. Nonetheless, caution is needed to interpret this result since their

\footnotetext{
${ }^{3}$ Tax return data in these studies are aggregated according to firm size, their industries, or locations of headquarters.
} 
tax returns and financial statements are based on different consolidation rules: unconsolidated tax returns filed in the US were matched with consolidated worldwide financial statements, and the leverage is measured based on consolidated worldwide balance sheets. ${ }^{4}$ Perhaps for this reason, as pointed out by the authors themselves, the simulated marginal tax rate based on financial statements better explains firms' worldwide consolidated leverage in their study.

\section{A simple theoretical model of debt with two tax rates}

In this section, we use a simple theoretical model to illustrate how tax affects corporate capital structure when there are two marginal tax rates. Consider a firm that aims to maximize its shareholder value, $V_{t}$, defined as:

$$
V_{t}=D_{t}+\beta E\left(V_{t+1}\right)
$$

where $\beta$ is the shareholder's discount factor, $\beta=1 /(1+\rho)$, and $\rho$ is the shareholder's discount rate. $D_{t}$ is dividend paid to the shareholder in period $t$, which equals to:

$$
D_{t}=F\left(K_{t-1}\right)-I_{t}+B_{t}-(1+r) B_{t-1}-\gamma\left(B_{t-1}\right)-T_{t}
$$

where $F\left(K_{t-1}\right)$ is the value of the firm's output, which depends on the capital stock at the end of the previous period, $K_{t-1}, I_{t}$ is new investment in period $t, B_{t}$ is new one-period debt issued in period $t, r$ is the interest rate, and $\gamma\left(B_{t-1}\right)$ is a convex

\footnotetext{
${ }^{4}$ For tax purposes, a U.S. parent corporation typically files a consolidated tax return that includes net income or loss only from all its domestic subsidiaries plus repatriations of profits from the foreign subsidiaries.
} 
cost of borrowing. $T_{t}$ is taxation, defined as:

$$
T_{t}=\left\{\begin{array}{c}
\tau_{L} Y_{t} \text { if } Y_{t}<H \\
\tau_{L} H+\tau_{H}\left(Y_{t}-H\right) \text { if } Y_{t} \geq H
\end{array}\right.
$$

where $Y_{t}$ is taxable profit, defined as:

$$
Y_{t}=F\left(K_{t-1}\right)-\delta K_{t-1}-r B_{t-1}
$$

and there is a progressive rate schedule, with a marginal rate of $\tau_{L}$ below the threshold $H$, and a marginal rate of $\tau_{H}$ above $H$, with $\tau_{H}>\tau_{L}$. The rate of depreciation relief for capital expenditure is assumed for simplicity to be equal to the true depreciation rate, $\delta$. The equation of motion of the capital stock is $K_{t}=(1-\delta) K_{t-1}+I_{t}$.

The firm chooses $K_{t}$ and $B_{t}$ to maximize $V_{t}$. The first-order conditions are:

$$
\begin{gathered}
K_{t}^{*}:\left\{\begin{array}{c}
F_{K}\left(K_{t}^{*}\right)-\delta=\frac{\rho}{1-\tau_{L}} \text { if } Y_{t}<H \\
F_{K}\left(K_{t}^{*}\right)-\delta=\frac{\rho}{1-\tau_{H}} \text { if } Y_{t}>H
\end{array}\right. \\
B_{t}^{*}:\left\{\begin{array}{l}
\gamma^{\prime}\left(B_{t}^{*}\right)=\rho-r\left(1-\tau_{L}\right) \text { if } Y_{t}<H \\
\gamma^{\prime}\left(B_{t}^{*}\right)=\rho-r\left(1-\tau_{H}\right) \text { if } Y_{t}>H
\end{array}\right.
\end{gathered}
$$

These first-order conditions indicate that the optimal level of debt is positively related with the firm's marginal tax rate, given its tax bracket. In contrast, the optimal level of capital stock is affected negatively by the firm's marginal tax rate since $F_{K}\left(K_{t}\right)<0$. Therefore, our theoretical model predicts that all else equal, an increase in the firm's marginal tax rate will result in a higher level of debt and a lower level of capital stock in the equilibrium, which implies a higher leverage ratio.

The key point that we want to make here is that, although the optimal level of debt (and the capital stock) depends on whether taxable profit is below or above 
the threshold, this does not depend on whether taxable profit before interest $\left(Z_{t}=\right.$ $\left.Y_{t}+r B_{t-1}\right)$ is above or below the threshold. That is, if $Y_{t}<H$, the optimal level of debt is independent of whether $Z_{t}<H$ or $Z_{t}>H$. To put it another way, suppose that $Z_{t}>H$, the firm then is incentivized to use more debt because at the margin it initially faces a high tax rate, $\tau_{H}$. This may take the firm to the threshold. But if we observe the firm at a position strictly below the threshold, then the usual first-order condition using $\tau_{L}$ must apply, and the higher tax rate $\tau_{H}$ is irrelevant. In our empirical analysis, we therefore use the after-financing marginal tax rate as a proxy for the tax incentives to use debt that firms face.

Note that the first order conditions are not defined at the threshold where $Y_{t}=$

$H$. At this point we have only that $\frac{\rho}{1-\tau_{L}}<F_{K}\left(K_{t}^{*}\right)-\delta<\frac{\rho}{1-\tau_{H}}$, and $r\left(1-\tau_{H}\right)<$ $\rho-\gamma^{\prime}\left(B_{t}^{*}\right)<r\left(1-\tau_{L}\right)$. In our empirical analysis, we therefore also estimate the impact of tax while excluding companies that are close to the threshold as a robustness check (Section 6.2).

\section{Empirical model}

The literature suggests that leverage is highly persistent over time due to adjustment costs (Fischer et al., 1989; Hovakimian and Titman, 2001; Flannery and Ragan, 2006; Lemmon et al., 2008). To capture this adjustment process, we use a general dynamic adjustment model of leverage specified as Equation (6) similar to that used by Lemmon et al. (2008):

$$
\operatorname{Lev}_{i, t}=\alpha_{0}+\alpha_{1} \operatorname{Lev}_{i, t-1}+\beta_{1} M T R_{i, t}+\beta_{2} M T R_{i, t-1}+\gamma_{1} Z_{i, t}+\gamma_{2} Z_{i, t-1}+\mu_{i}+\theta_{t}+\epsilon_{i, t}
$$

where $L e v_{i, t}$ is the leverage ratio of company $i$ in year $t$. As discussed in Section 3, conditional on the observed tax brackets, firms' tax incentives to borrow are captured by the after-tax marginal tax rate. Thus, we use the variable $M T R_{i, t}$, the after-financing marginal tax rate faced by company $i$ in year $t$, as the key 
explanatory variable. We control for a vector of firm-level non-tax characteristics $Z_{i, t}$, which likely affect leverage, including size, tangibility, and profitability. $\mu_{i}$ is an unobserved company-specific fixed effect; $\theta_{t}$ is a time effect; and $\epsilon_{i, t}$ is an unobserved company-level, time-varying shock.

Re-arranging Equation (6), we obtain an error-correction specification:

$$
\begin{aligned}
\triangle \text { Lev }_{i, t}= & \alpha_{0}+\left(\alpha_{1}-1\right) \operatorname{Lev}_{i, t-1}+\left(\beta_{1}+\beta_{2}\right) M T R_{i, t-1}+\left(\gamma_{1}+\gamma_{2}\right) Z_{i, t-1}+\beta_{1} \triangle M T R_{i, t} \\
& +\gamma_{1} \triangle Z_{i, t}+\mu_{i}+\theta_{t}+\epsilon_{i, t}
\end{aligned}
$$

where the long-run effect of the corporate tax rate on leverage is given by $\left(\beta_{1}+\right.$ $\left.\beta_{2}\right) /\left(1-\alpha_{1}\right)$, and $\left(1-\alpha_{1}\right)$ measures the convergence speed of the leverage ratio towards its long-run target. Similarly, the long-run effect of other control variables in (7) is measured as $\left(\gamma_{1}+\gamma_{2}\right) /\left(1-\alpha_{1}\right)$. The Error Correction Model nests the partial adjustment and accelerator models as special cases, which has the advantage of separating the long-run determinants of the level of leverage from the short-run adjustment dynamics. Our empirical specification is similar to the partial adjustment model reported in Lemmon et al. (2008). Equation (7) is estimated using the difference GMM estimator (Arellano and Bond, 1991). As discussed in details by Flannery and Hankins (2013), with fixed effects and the lag dependent variable on the right hand side, the difference GMM estimator can consistently estimate the speed of adjustment and coefficients on other independent variables and hence, is a better option for estimating dynamic panel data than the Ordinary Least Squares (OLS) and the Fixed-Effects (FE) estimators.

It is worth noting that we treat the marginal tax rate as endogenous in the difference GMM estimations. Suppose the $M T R$ s follow the process $M T R_{i, t}=$ $\rho M T R_{i, t-1}+v_{i, t}$ where $0<|\rho|<1$ and $v_{i, t}$ is an i.i.d. process. If $v_{i, t}$ is correlated with $\epsilon_{i, t}\left(E\left[v_{i, t}, \epsilon_{i, t}\right] \neq 0\right)$, we have $E\left[M T R_{i, t}, \epsilon_{i, t}\right] \neq 0$. For example, a firm that experiences large positive demand shocks in year $t$ may have more internal funds 
and higher taxable profits. Consequently, the firm may have both high marginal tax rate and low incentive to borrow, which would be consistent with the peckingorder theory of capital structure. In the first-differenced equation, the endogeneity of $M T R_{i, t}$ implies $E\left[\triangle M T R_{i, t}, \triangle \epsilon_{i, t}\right] \neq 0$ and $E\left[\triangle M T R_{i, t-1}, \triangle \epsilon_{i, t}\right] \neq 0$. Consequently, the estimate for the coefficient, $\widehat{\beta}_{1}$, and the estimate for the long-run tax effect on leverage, $\left(\widehat{\beta}_{1}+\widehat{\beta}_{2}\right) /\left(1-\widehat{\alpha}_{1}\right)$, are both likely to be biased. To deal with this issue, we use an instrumental variables estimation approach that is standard in the dynamic panel literature (Anderson and Hsiao, 1982). This method has recently been used by Weber (2014) to analyze a similar issue. ${ }^{5}$ Suppose that the error term $\epsilon_{i, t}$ is not serially correlated, then we have

$$
E\left[M T R_{i, t-l}^{\prime} \triangle \epsilon_{i, t}\right]=0
$$

for $l>1$

Equation (8) indicates we can use $M T R_{t-2}$ and further lags of $M T R$ as instruments for $M T R_{i, t}$ in the difference GMM estimations, which holds even when $M T R \mathrm{~s}$ are persistent $(0<\rho<1)$. However, if there is first-order serial correlation in $\epsilon_{i, t}$, we will have $E\left[v_{i, t-2}, \epsilon_{i, t-1}\right] \neq 0$ and $E\left[M T R_{i, t-2}^{\prime}, \triangle \epsilon_{i, t}\right] \neq 0$. This means that we can only use $M T R_{t-3}$ and further lags of $M T R$ as instruments. In practice, we formally test the order of serial correlation in $\epsilon_{i, t}$ and find first-order but no higher order serial correlation. Thus, we use lagged $M T R$, lagged leverage, profitability, tangibility and firm size (dated at t-3 and t-4) as the set of instruments in the difference GMM estimations. In principle, we can use lag variables dated at t-3 and earlier as instruments. We choose to use only lag variables dated at t-3 and t-4 since our panel data is short in $T$. Using lag variables dated earlier is also likely to lead to weak instruments. We formally test the validity of our IVs using the Hansen

\footnotetext{
${ }^{5}$ Weber (2014) estimates the elasticity of individual taxable income with respect to the tax rate. A similar endogeneity problem arises as the personal tax rate is likely to be correlated with the unobserved shocks, which in turn affects taxable income.
} 
test. As an alternative strategy, we use the lags of the before-financing $M T R$, and the lags of leverage, profitability, tangibility and size (all dated at t-3 and t-4) as a new set of instruments. It is worth noting that some studies use directly the before-financing marginal tax rate as the explanatory variable in the estimations. However, our theoretical model in Section 3 suggests that firms' optimal debt policy does not depend on the before-financing marginal tax rate, although it may serve as an instrument for $M T R_{i, t}$.

To achieve identification of Equation (7), we rely on changes in the UK statutory corporate income tax and on the fact that the corporation tax rate schedule in the UK has several marginal rates during fiscal years 2001-2009. We start with 2001, the earliest year we have access to firms' tax returns. Figure 1 illustrates the marginal tax rate schedule graphically in fiscal years 2001 and 2008. Figure 1 shows some substantial jumps in the statutory marginal tax rate, for example at the $£ 300,000$ threshold for taxable profit. Another significant kink arises due to the zero starting rate for companies with less than $£ 10,000$ taxable profits in place between fiscal years 2002 and 2005. Appendix A reports the statutory marginal tax rate associated with each bracket of taxable profit during our sample period in more details.

Several factors may confound our identification. First, it is possible in principle that the corporation tax gains to greater use of debt are outweighed to some extent by the taxation of the interest received by the lender (Miller, 1977). However, there is no reason to suppose that corporation tax rates might be correlated with the variation in tax rates of the lenders and thus, our empirical strategy remains valid. There was also little change in the personal income tax rate schedule in the UK during our sample period. Second, a firm may shift into a higher tax bracket when it grows more profitable, larger in size, or more tangible. Absent the changes in tax incentives, the firm may still lever up in such cases as it becomes easier to borrow. Throughout our analysis, we then control for firms' profitability, size, and 
tangibility. In this way, we are likely to separate out the tax effects on leverage.

\section{Sample construction and data description}

\subsection{Sample construction}

We use confidential tax returns collected by Her Majesty's Revenue and Customs (HMRC), the UK tax authority, which covers the universe of companies that file a corporate income tax return in the UK during fiscal years $2001-2009 .{ }^{6}$ Data before 2001 is not available. UK tax returns are filed on an unconsolidated basis. The tax return data provides precise information on the tax position of each company in each period. However, it contains little information on financial statement variables. In particular, it does not contain information on debt or interest payments. We therefore merge the tax return data with the unconsolidated accounting data from the financial statement database FAME (provided by Bureau van Dijk) by the company identification number, and the end dates of the tax-returns and the financial statements. ${ }^{7}$ As the capital structure of financial companies is a rather different concept from that of non-financial companies, we exclude the financial sector from our analysis.

We use information from balance sheets to construct the leverage ratio, defined as the sum of short-term and long-term debt expressed as a proportion of total debt and book equity. ${ }^{8}$ As a large proportion of firms in the tax returns did not report any information about their debt in FAME, we lose a considerable number of observations. ${ }^{9}$ We include company size, tangibility and profitability as our

\footnotetext{
${ }^{6}$ The UK corporate tax return form is called the CT600 form. The confidential tax return data is accessible to UK based researchers and it is provided by the HMRC through the secured Datalab.

${ }^{7}$ Each firm is assigned a unique identifier (ID) in both the tax return data and the accounting data by the HMRC. We use this firm ID to carry out the matching. We keep only firms with 12 months in each accounting period, which are the majority of firms in our sample.

${ }^{8}$ As firms in our sample are private, we do not observe the market value of their equity. Hence, book equity is included in the denominator of the leverage ratio.

${ }^{9}$ In unreported exercises, we compare the size, tangibility and profitability between firms with
} 
main control variables since these have been found to be among the most reliable factors for explaining leverage (Frank and Goyal, 2009; Graham and Leary, 2011). Appendix B provides a detailed description of the variable construction for our empirical analysis.

Each company in the sample reports at least 4 consecutive years of observations after we winsorize key variables at the bottom and top 1 percent, which is necessary to implement our estimations. ${ }^{10}$ The final sample contains 16,124 companies and 93,259 company-year observations (the full sample), of which 9,439 companies (51,051 company-year observations) never experienced taxable losses during the sample period (the positive-profit-only sample). Throughout our analysis, we will pay special attention to the positive-profit-only sample since the tax returns provides the most accurate measure for the tax incentives to use debt for this type of firms and hence, estimations based on this sample is largely free of measurement errors in the tax variable.

Firms in our sample are private, around $70 \%$ of the which are domestic standalone businesses while the rest belongs to a corporate group. Our sample only consists of private firms as a result of matching tax returns with financial statements. As mentioned previously, we match unconsolidated tax returns with unconsolidated financial statements for consistency. However, for listed firms Amadeus generally only provides consolidated accounts, which cannot be matched with tax returns compiled on an unconsolidated basis. Consequently, our matched sample only contains private firms.

Panel A of Table 1 provides summary statistics of key variables based on the positive-profit-only sample. Panel B reports summary statistics of key variables for firms that experienced losses at least once during the sample period. ${ }^{11}$ The and without leverage information in FAME. We find that firms without leverage information tend to be smaller, less tangible, and less profitable.

${ }^{10}$ We choose to winsorize variables rather than to exclude observations with extreme values so that the sample size will not be reduced.

${ }^{11}$ As a result, Panel B of Table 1 is based on firm-year observations that are not in the positiveprofit-only sample but are in the full sample. 
average leverage ratio for private firms in our sample is rather high-close to $50 \%$ in both samples. This is consistent with Brav (2009) in that private firms rely more heavily on debt as a source of financing, compared with publicly traded firms. Mechanically, firms in the positive-profit-only sample report more taxable profits and higher marginal tax rates on average, relative to the firms that experienced losses. We also observe that profit-making firms tend to be larger and less tangible. In Panel $\mathrm{C}$, we conduct the $\mathrm{t}$ test and the Wilcoxon test of the null hypothesis that the two groups of firms have equal means of taxable profits, the after-tax marginal tax rate, size, tangibility, profitability and leverage. Both the t test and the Wilcoxon test strongly reject the null hypothesis of equal means across the two samples (the p-values of these statistics are essentially zero). It is worth noting that the number of observations is large for both samples, which could explain why the $\mathrm{t}$ test and the Wilcoxon test statistics are substantial.

\subsection{Descriptive analysis of marginal tax rates}

Figure 2 plots the distribution of companies' statutory marginal tax rates based on the full sample for the period 2001-2009. For loss-making firm-year observations, we assume that the marginal tax rate is zero when plotting these figures. ${ }^{12}$ Figure 2 shows rich variation in both measures of marginal tax rates across companies. Table 2 reports the transitional probability matrix for companies' taxable profits from year t-1 to year t, shown separately for the positive-profit-only sample and the full sample. Table 2 reveals persistence in allocations to tax brackets for firms in both samples. For firms always making positive taxable income, the probability of staying within the same tax bracket from period t-1 to period $t$ is around $70 \%$ $80 \%$. Firms' loss-making status is also rather persistent: when a company is in the loss-making position in period t-1, with around $70 \%$ probability it would remain

\footnotetext{
${ }^{12}$ Firms with taxable profits below $£ 10,000$ during the fiscal years 2002-2005 faced zero statutory marginal tax rate, which adds to the mass at zero in Figure 2.
} 
non-taxable in period t. Despite the persistence, there is still considerable timeseries variation in companies' tax status as suggested by the non-zero off-diagonal figures in Table 2. Together with a number of tax rate reforms during the sample period, these changes in companies' tax status create rich variation in the marginal tax rate which we can exploit.

As a further check, Table 3 reports the number of tax status changes within companies. For the positive-profit-only sample, around a quarter of companies never changed their tax brackets. These firms serve as the control group in our estimations. Around $28 \%$ of companies changed their location on the tax rate schedule once and more than $20 \%$ of companies changed their location on the rate schedule at least three times. At the $£ 300,000$ threshold, around $35 \%$ of companies in the positive-profit-only sample moved into or out of this tax bracket at least once during the sample period. For the full sample, around $80 \%$ of firms changed tax bracket at least once during the sample period, and around half of the companies moved in or out of taxable losses at least once.

\section{Estimating tax effects on capital structure based on tax returns}

\subsection{Benchmark result}

We begin our estimation using the positive-profit-only sample, for which we can most accurately measure tax incentives for borrowing faced by firms. Without loss making firms, we precisely observe firms' marginal tax rates and hence, estimations should be largely free of measurement errors. Table 4 reports the estimation results based on Equation (7). We apply the difference GMM estimator (Arellano and Bond, 1991), which uses the set of instruments as we explained in Section $4 .^{13}$

\footnotetext{
${ }^{13}$ We conduct the GMM estimation using the STATA command xtabond2 (Roodman, 2009).
} 
As our benchmark instrumenting strategy, we use the lags of $M T R$, the lags of leverage, profitability, tangibility and firm size, as the set of instruments for $M T R_{i, t}$ in the GMM estimations. We also specify other control variables and the lag dependant variable as endogenous. As discussed previously, we use lag variables dated at t-3 and t-4 as instruments based on the serial correlation test of $\Delta \epsilon_{i, t}$ (reported in Table 4), which suggests first-order serial correlation in $\epsilon_{i, t}$. Note that if the error term $\epsilon_{i, t}$ is not serially correlated, we would reject the null hypothesis that there is no $\operatorname{AR}(1)$ type of serial correlation in $\Delta \epsilon_{i, t}$, and we would accept the null hypothesis that there is no higher order of serial correlation in the error term of the first-differenced equation. In Table 4, we strongly reject the null hypothesis that there is no $\operatorname{AR}(1)$ or $\operatorname{AR}(2)$ type of serial correlation in $\Delta \epsilon_{i, t}$, but we cannot reject the null hypothesis that there is no $\mathrm{AR}(3)$ type of serial correlation in $\Delta \epsilon_{i, t}$. Correspondingly, these results suggest that there is $\operatorname{AR}(1)$ but no higherorder serial correlation in $\epsilon_{i, t}$ and thus, only the third or further lags of variables in our instrument set could be valid instruments as discussed earlier.

In Column 1, the GMM estimation yields positive estimates for coefficients on both $\triangle M T R_{i, t}$ and on $M T R_{i, t-1}$. We obtain a positive and significant long-run tax effect on leverage that is around 0.76. The estimated convergence speed is around 0.24, which is close to that estimated by Lemon et al. (2008) regarding large US listed non-financial firms in their GMM estimations. The Hansen test cannot reject the null hypothesis that the IVs are exogeneous even at the 10 percent level (the p-value of the test statistics is 0.754$)$.

As a robustness check, in Column 2 we include the lags of the before-financing $M T R$, rather than the lags of the after-financing $M T R$, in the set of instruments. Here, we continue to obtain a positive and significant long-run tax effect on leverage, and the magnitude of the point estimate on $M T R^{I V b e f o r e}$ is around 1.397. Nonetheless, this point estimate is associated with a larger standard error than that of the point estimate on $M T R$ in Column 1. This result is not surprising as compared 
with the lags of the $M T R$, the lags of the before-financing $M T R$ are less strongly correlated with the current after-financing $M T R$.

In Columns 3-5, we use the full sample including loss-making observations. A marginal increase in the interest cost of a loss-making company does not typically have an immediate impact on tax liabilities, but instead increases the tax loss carried forward to set against profit in subsequent periods. UK firms are allowed to carry losses back for 12 months or forward indefinitely. ${ }^{14}$ Additional variation in the marginal tax rate is therefore introduced and its value depends on how long the company expects to reach a positive taxable profit. There have been a number of attempts to estimate such effective tax rates, the best-known being Graham (1996a). ${ }^{15}$ In our study, we consider two approaches: we either set MTR to zero for loss-making observations or use the "perfect-foresight" marginal tax rate (PMTR). The $P M T R$ is constructed assuming firms can fully anticipate their future tax status. In practice, we use the tax returns to decide whether and when loss-making firms became taxable again, or whether the firm carried loss back. PMTR is set to 0 if the firm made losses throughout the sample period. We provide more details about the construction of the PMTR in Appendix B. It is worth noting that both the MTR and PMTR for loss-making observations may deviate from the true tax incentives for borrowing, given the strong assumptions we make when constructing these variables. Thus, estimations based on the full sample is likely to be affected by measurement errors.

Column 3 reports GMM estimation results assuming $M T R$ is zero for lossmaking firms. Here, we use the lags of $M T R$, together with the lags of leverage, profitability, tangibility and firm size, in the difference GMM estimation. We find

\footnotetext{
${ }^{14}$ Note that companies are also, subject to some limitations, able to set losses in one company against profit in another company in the same group, in which case, the relevant tax rate is in principle that of the group member to which losses are transferred. We do not observe the recipient company. However, only around $5 \%$ of firms in our sample are part of a UK domestic group.

${ }^{15}$ See also the earlier studies that exploit cross-section variation in marginal tax rates due to losses (Shevlin, 1987, 1990; Devereux, 1989; Devereux et al., 1994; and Altshuler and Auerbach, 1990).
} 
a long-run tax effect on the leverage ratio of around 1.04, which is significant at the 1 percent level. One caveat is that we do not observe the actual amount of losses that firms made in the tax returns-the taxable income is simply recorded as zero in this case. Therefore, we cannot calculate the before-financing MTR for loss-making observations and consequently, we do not use the lags of the before-financing $M T R$ as instruments for the full sample. Columns 4 reports the GMM estimation result using PMTR as the proxy for the tax incentives, and we use the lags of the PMTR instead of lags of $M T R$ in the set of instruments. In Column 4, we obtain a long-run tax effect of around 0.98. One concern about PMTR is that, as explained in more details in Appendix B, we impose especially strong assumptions about the first and the last observations in the sample for each company if it is in a loss-making position in those years: if the firm made a loss when it first appears in the sample, we do not observe whether the company carried losses backward; and if a firm made a loss when it exit the sample, we do not observe whether it carried loss forward in the future. Therefore, in Column 5 we repeat the approach of Column 4 but omit the first and the last observations for each firm. Despite the smaller sample, the long-run coefficient on PMTR $R^{\text {Exclude }}$ in Column 5 has a similar magnitude to that on PMTR in Column 4.

Throughout Table 4, we cannot reject the null hypothesis that our set of instruments are exogenous. In fact, apart from Column 4, the p-value associated with the Hansen test statistics exceeds the 10 percent level. The serial correlation test of the error term suggests $\operatorname{AR}(1)$ but no higher-order serial correlation in $\epsilon_{i, t}$. The serial correlation test of the error term lends further support for our choice of lag orders for our IVs. We obtain similar serial correlation test results in tables in the rest of the paper and hence, we do not report the statistics for brevity. ${ }^{16}$

\footnotetext{
${ }^{16}$ The serial correlation test results are available upon request.
} 


\subsection{Excluding bunchers}

One remaining confounding factor is that firms may use debt to shift into a lower tax bracket. Such firms' taxable income would likely bunch just below the threshold. To investigate this issue, we plot the distribution of firms' taxable income based on the positive-profit-only sample in Figure 3. Figure 3 shows the number of firms in each bin of taxable income based on the tax returns, where the bin width is set to be $£ 20,000$. Without kinks in the corporate tax rate schedule, the distribution of taxable income is likely to be smooth. However, we observe significant bunching of taxable income around the $£ 300,000$ threshold. To have a closer look, Figure 4 plots the distribution of taxable income (the red line) around the $£ 10,000, £ 50,000$, 3300,000 , and $£ 1,500,000$ thresholds, respectively. These detailed figures show more clearly that bunching of taxable income mostly occurs around the $£ 10,000$ and $£ 300,000$ thresholds. Interestingly, when we focus on the before-financing taxable income (brown bars), its distribution appears to be smooth around all the kink points. Nevertheless, the distribution of taxable income before deducting capital allowances (and after deducting interest expenses) is also smooth (the black line). Hence, it is likely that firms use debt as well as other tax shields, such as capital allowances, to shift just below the threshold.

In Table 5, we repeat the exercises as in Table 4 but excluding bunching firms around the $£ 10,000$ and $£ 300,000$ thresholds. More specifically, we drop firms with taxable profits between $£ 9,600$ and $£ 10,000$, and between $£ 290,500$ and $£ 300,000$. In unreported exercises, we use wider ranges to identify the bunching firms but results are not sensitive to this choice. Excluding bunching firms reduces our sample size. We report the GMM estimation results based on the positive-profit-only sample in Columns 1 and 2. In Column 1, we report the GMM estimation results using our benchmark instrumenting strategy. In Column 2, we use the lags of the before-financing $M T R$ in the set of instruments instead. Excluding these bunching firms barely changes our benchmark estimation results. We continue to find a sub- 
stantial positive tax effect on corporate leverage in the long run, whose magnitude is similar to that reported in Table 4.

In Column 3 and 4, we report the GMM estimation results when we exclude bunching observations from the full sample. Ideally, we would also like to exclude observations bunching just below the zero taxable income for the full sample, but this is impossible because the taxable profits are truncated at zero in the tax returns. With this caveat in mind, we continue to find a long-run tax effect on leverage similar to the corresponding columns in Table 4, regardless whether we use the $M T R$ (Column 3) or the PMTR (Column 4) as the proxy for the tax incentives to use debt.

\subsection{Asymmetric tax effects}

Heider and Ljungqvist (2015) find that tax increases affect firms' capital structure differently from tax decreases. To test whether the tax effects are asymmetric in our sample, we construct a dummy variable Increase $_{i, t}$ that equals 1 if firm $i$ 's marginal tax rate based on the tax returns increases from year $t-1$ to year $t$. We then interact this dummy variable with both $M T R_{i, t-1}$ and $\triangle M T R_{i, t}$ and include

these interaction terms as additional regressors in Equation (7). More specifically, we estimate the specification below using the difference GMM estimator:

$$
\begin{aligned}
\triangle \text { Lev }_{i, t}= & \alpha_{0}+\left(\alpha_{1}-1\right) \text { Lev }_{i, t-1}+\left(\beta_{1}+\beta_{2}\right) \text { MTR }_{i, t-1}+\beta_{3} \text { Increase }_{i, t} \times M T R_{i, t-1} \\
& +\left(\gamma_{1}+\gamma_{2}\right) Z_{i, t-1}+\beta_{1} \triangle M T R_{i, t}+\beta_{4} \text { Increase }_{i, t} \times \triangle M T R_{i, t} \\
& +\gamma_{1} \triangle Z_{i, t}+\mu_{i}+\theta_{t}+\epsilon_{i, t}
\end{aligned}
$$

The results are reported in Table 6 . If the effects of tax rate changes on leverage are asymmetric, we should find the estimated coefficients on these interaction terms to be significantly different from zero. We do not find any evidence for asymmetry in Column 1 based on the positive-profit-only sample-the estimated coefficients on 
Increase $_{i, t} \times M T R_{i, t-1}$ and Increase $_{i, t} \times \triangle M T R_{i, t}$ are both insignificant.

Nonetheless, based on the full sample including loss-making firms, in Column 2 we find that private firms in our sample respond more to a tax rate decrease in the long run than to tax rate increase-the estimated coefficient on Increase $_{i, t} \times$ $M T R_{i, t-1}$ is both negative and significant at the 5 percent level. The estimated coefficient on Increase $_{i, t} \times \triangle M T R_{i, t}$ is also negative although it is insignificant. In Column 3, we use the perfect-foresight $M T R$ as a proxy for the tax incentive to use debt and we continue to find a smaller long-run reaction to an increase in the $P M T R$ than that to a decrease in the PMTR. In this specification, we also find some evidence for a smaller response of leverage to increase in the PMTR in the short run, as the estimated coefficient on Increase $_{i, t} \times \triangle M T R_{i, t}$ is negative and significant at the 10 percent level. It is worth noting that we only find a significant asymmetric effect when we include loss-making firms. Thus, our result suggests that moving into a loss-making position-and therefore facing a lower effective marginal tax rate-is associated with a more pronounced reduction in debt.

\subsection{Domestic stand-alone firms versus multinationals: Ex- ternal debt}

In our sample around $70 \%$ of companies are stand-alone UK companies and around $26 \%$ of companies belong to a multinational group. It is of policy interest to analyze the effects of taxation for such smaller, domestic stand-alone companies. The response of the capital structure with respect to changes in the marginal tax rate is also likely to be different between domestic stand-alones and multinationals. First, unlike domestic firms, multinationals can allocate their debt internally across different tax jurisdictions to reduce their worldwide tax liabilities (see, for example, Desai et al., 2004). Moreover, multinational companies may-subject to anti-avoidance rules-have the opportunity to borrow externally in different jurisdictions, and allocate internal debt so that high tax subsidiaries are financed by 
low tax entities in the same group. Second, UK multinationals were subject to the worldwide tax system for foreign profits repatriation until 2009 (Arena and Kutner, 2015). Under the worldwide system, repatriated dividends form part of the taxable income which we use to calculate the marginal tax rates. Thus, even at the unconsolidated level, foreign profits repatriation may affect multinationals' marginal tax rate. ${ }^{17}$ Thus as a robustness check, we focus on external debt in this section and compare whether domestic stand-alone firms are different from firms that are a part of a multinational group.

We identify whether a company is a domestic stand-alone or a part of a multinational group using information on companies' ownership structure from FAME. ${ }^{18}$ More specifically, FAME records whether a company is independent or not. ${ }^{19}$ If a company is not independent, we know the name and location of its global ultimate owner. We define a company to be a part of a multinational group if it satisfies one of the following criteria: 1) the company itself is independent and it has foreign subsidiaries outside of the UK; 2) it is a subsidiary of a group with a UK ultimate owner and which has foreign subsidiaries; 3) it is a subsidiary of a group with a non-UK ultimate owner. We define a company to be part of a domestic corporation group if: 1) it is independent and has only domestic subsidiary; 2) or it is a subsidiary of a group with a UK ultimate owner and which has no foreign subsidiary. The rest of the sample are domestic stand-alone companies.

We provide summary statistics of key variables for domestic stand-alones and

\footnotetext{
${ }^{17}$ For example, when a multinational company repatriates dividends, the amount of repatriated dividends are first grossed up to reflect the amount of repatriated before-tax profits. This amount of grossed-up foreign profits is then added to the companies' total taxable profits that are subject to the UK corporation tax under the worldwide system. Foreign profits repatriation may affect our calculation of multinationals' marginal tax rate as firms may be pushed into a higher tax bracket. To avoid double taxation, companies can claim credits on foreign tax paid. If the corporate income tax rate is lower in the host country than that in the UK, the company's tax liability to the UK governent on repatriated foreign profits equals to the grossed-up foreign profits multiplied by the differential corporate income tax rate.

${ }^{18} \mathrm{~A}$ caveat of our approach is that the ownership information is only available for the most recent year for each firm in FAME. Therefore, we need assume that firms' ownership structures did not change during the sample period.

${ }^{19}$ We define a company to be independent if no other company owns more than $50 \%$ of its total shares.
} 
for companies that belong to a multinational group in Appendix C. ${ }^{20}$ We observe that relative to domestic stand-alones, companies that are a part of a multinational group tend to be larger and less profitable (indicated by size and profitability). On average, companies belonging to a multinational group report more taxable profits, which suggests that they may face a higher marginal tax rate than domestic standalones. Interestingly, companies that belong to a multinational group do not on average have a higher leverage ratio. This is possible if multinational firms allocate more debt in jurisdictions with a higher corporate income tax rate than that in the UK. In Table C2, we also observe that both domestic stand-alones and multinational companies frequently change their tax brackets.

Table 7 presents the GMM estimation results when the external leverage ratio is the dependent variable in Equation (7). We estimate using the positive-profit-only sample in Columns 1 and 2, and the full sample in Columns 3 and 4. Throughout different columns in Table 8 , we use the $M T R_{i, t}$ to capture the tax incentives that firm $i$ faces in year $t$, and use the lags of the $M T R$, together with lags of leverage, tangibility and firm size, as the set of instruments. We continue to find a positive and substantial long-run tax effect on capital structures when we focus on domestic stand-alone companies (Columns 1 and 3). Companies that are part of a multinational group also change their external leverage ratio when facing a change in the marginal tax rate (Columns 2 and 4 ).

We obtain a somewhat mixed result comparing the sensitivity of external leverage toward changes in the tax incentives between the two types of firms. Based on the positive-profit-only sample, the estimated long-run tax effect on external leverage for the two types of firms are similar (1.000 in Column 1 versus 1.104 in Column 2). However, based on full sample, we find the external leverage of firms that are part of a multinational group is less sensitive to changes in tax incentives than that for domestic stand-alone firms (0.285 in Column 4 versus 0.920 in Column

\footnotetext{
${ }^{20}$ We do not report the result using the sample of firms that are part of a domestic group as they only consist of around $5 \%$ of the whole sample.
} 
3). This latter result suggests that there is possible substitution between external and internal debt for multinationals, as discussed in Desai et al. (2004). ${ }^{21}$ And such substitution effect is perhaps stronger when a subsidiary is in the loss-making position. The smaller sensitivity estimated for multinationals in Column 4 may also relate to foreign profits repatriation, as discussed at the beginning of this section. We also find that companies that are part of a multinational group adjust their external leverage ratio much faster than domestic stand-alone companies (0.34 versus 0.27 based on the positive-profits-only sample, and 0.49 versus 0.29 based on the full sample). This suggests that the affiliation to a multinational corporation group may help reduce companies' adjustment costs associated with external borrowing.

\section{Marginal tax rate based on tax returns: A bet- ter measure to capture capital structure tax incentives?}

\subsection{Tax returns versus financial statements}

The major advantage of using tax return data to study the effects of corporate taxes on capital structure is that it provides accurate information on companies' tax status. By contrast, tax incentive measures based on financial statements are likely to be infected with large measurement errors. It is well known that measurement errors of this type will create an attenuation bias in the estimate. With matched tax returns and financial statements for a same sample of firms, we investigate the importance of measurement errors in this section.

Table 8 illustrates the correspondence between the taxable income reported in the tax return data and the estimated taxable income based on the accounting data

\footnotetext{
${ }^{21}$ To understand the tax effects on capital structure for firms that are a part of a multinational group, one needs to estimate a more sophisticated model in which firms can simultaneously choose how much to borrow externally and internally, which is beyond the scope of the current study.
} 
from FAME, using both samples. It reveals considerable discrepancies between these two data sources. In Panel A, based on the positive-profit-only sample, $18 \%$ of observations within the $£ 0-50,000$ tax bracket "over-reported" taxable income in financial statement. This discrepancy is particularly severe when a company makes a loss - only around $50 \%$ of companies with taxable losses report a loss in their financial statements. The univariate statistics for these two types of taxable income also differ considerably. For firms in the positive-profit-only sample, the mean of taxable income reported in tax returns is $£ 561,260$ and that reported in financial statements is $£ 680,197$. The difference is even larger for firms that ever make losses: the average taxable income reported in tax returns is $£ 121,865$, compared with an average of $£ 525,264$ according to the same firms' financial statements. This is consistent with the observation above that a large proportion of firms report losses in tax returns but not in financial statements. Taking profit-making and lossmaking firms together, the sample average of taxable income based on tax returns is $£ 362,205$ and that based on financial statements is $£ 610,010$. The median levels of taxable income from the two sources also differ substantially-£40,580 based on tax returns and $£ 93,000$ based on financial statements. We report more details of the distributions of the two types of taxable profits in Panel A. Overall, our analysis reveals a non-trivial bias in taxable income estimated using financial statements.

Panel B reports the correlations between different measures of the marginal tax rate: the after- and before-financing marginal tax rates calculated based on tax return data, $M T R$ and $M T R_{\text {before }}$, the after- and before-financing marginal tax rates based on financial statements, $M T R^{F S}$ and $M T R_{\text {before }}^{F S}$, as well as the perfect-foresight marginal tax rate based on the two data sources (PMTR and $\left.P M T R^{F S}\right)$. Panel $\mathrm{B}$ reveals that tax rates based on tax returns and financial statements are rather different. We find a partial correlation of around 0.6 between $M T R$ and $M T R^{F S}$, and a similar correlation between $M T R_{\text {before }}$ and $M T R_{\text {before }}^{F S}$. The correlation between PMTR and $P M T R^{F S}$ is only 0.5 . 
Our observation of the discrepancies between companies' actual taxable income and book income is consistent with the large literature on the existence of book-tax differences (Scholes and Wolfson, 1992; Cloyd et al., 1996; Plesko, 2000; Manzon and Plesko, 2001; Mills and Newberry, 2001; Desai, 2003). Such book-tax differences could arise due to different accounting rules for tax and for financial reporting and earnings management. Temporary book-tax differences arise as tax and financial reporting may have different rules for revenue and expenses recognition, such as how capital expenditures are depreciated. Permanent book-tax differences arise as revenue or expenses are accrued under one system but not the other. Moreover, as tax returns and financial statements are prepared for different purposes, companies have some incentive to report low taxable income to the tax authority, and to report high income in their financial statements. Although large book-tax differences may increase the probability of being audited by tax authorities, previous studies suggest that companies do not always conform their financial statements to their tax reports.

Our analysis suggests that marginal tax rates measured based on financial statements are rather different from those measured based on tax returns. Thus, using the former to estimate the tax effects on leverage is likely to generate large bias due to measurement errors, which points to the advantage of using actual tax returns. To test whether measurement errors make a material difference, we compare the GMM estimation results of Equation (7) using two versions of the marginal tax rate: one based on tax returns $(M T R)$ and the second based on financial statements $\left(M T R^{F S}\right)$. We report the results in Table 9 .

We start with the positive-profit-only sample, which is free of errors in the measurement of the marginal tax rate. Results based on this sample should provide the cleanest comparison. In Columns 1 and 2, we include the lags of $M T R$ (or $M T R^{F S}$ ) in the set of instruments (other IVs include the lags of leverage, profitability, tangibility, and firm size) in the difference GMM estimations. In Columns 3 and 4, we instead include lags of the before-financing marginal tax rate $\left(M T R^{I V b e f o r e}\right.$ or 
$\left.M T R^{F S_{-} I V b e f o r e}\right)$ in the set of instruments. We find that only MTR based on tax returns has strong explanatory power for corporate leverage (Columns 1 and 3 , while the estimated coefficient on $M T R^{F S}$ is not only smaller in magnitude but also insignificantly different from zero (Columns 2 and 4). Thus, without the availability of tax return data, we would conclude that there is little impact of the corporate taxes on firms' capital structure choices.

We re-conduct the comparison between $M T R$ and $M T R^{F S}$ using the full sample in Columns 5-8. In addition to the marginal tax rate, we also compare the explanatory power of $P M T R$ and $P M T R^{F S}$. It is worth noting that using the full sample including loss-making observations is likely to create measurement errors in all these tax measures. Thus, we should interpret the results based on the full sample with caution. To alleviate measurement errors as much as we can, we exclude the first and last observations for each firm if it was in the loss-making position in that year in the tax returns. In Columns 5-6, we continue to find that only $M T R$ has strong explanatory power to corporate leverage, while $M T R^{F S}$ does not carry significant explanatory power for leverage either in the short run or in the long run. Nonetheless, when we use $P M T R$ or $P M T R^{F S}$ to capture tax incentives for debt financing (Columns 7-8), we obtain positive and significant estimates for the coefficients on both $\triangle M T R_{i, t}$ and $M T R_{i, t-1}$ although the estimated long-run tax effect based on PMTR is significant at the 5 per cent while the corresponding long-run estimate based on $P M T R^{F S}$ is insignificant.

Results in Table 9 suggest that the marginal tax rate measured based on actual firm-level tax returns appear to have stronger explanatory power for our sample firms' capital structure choices, especially when we use the positive-profit-only sample where firms' marginal tax rates are most accurately observed in tax returns. Using financial statements to infer firms' marginal tax rates, on the other hand, we fail to find strong evidence of tax effects on capital structure. This result is likely to due to the attenuation bias caused by measurement errors in the marginal tax rate 
when we use information only from the financial statements, given the large booktax difference we document earlier. Book-tax difference is a common phenomenon among firms in the US and other countries where the tax and financial accounting standards differ. Thus, one implication of our finding is that studies using marginal tax rate based on financial statement information, rather than tax returns, may underestimate the true tax effects on leverage.

To make our analysis more complete, ideally we need to compare the explanatory power of two versions of the simulated marginal tax rate (SMTR, Graham, 1996a, 1996b), one based on tax returns and the other on financial statements. As we do not have information on losses in the tax returns, we are unable to construct the SMTR based on tax returns. Admittedly, this is a limitation of our study. However, in Table 8 we observe a rather poor correspondence between taxable profits from the tax returns and the taxable income estimated using the financial statements. The comparison is especially poor when the company is in a loss-making position: more than half of the observations reporting losses for tax purposes report positive taxable income in the financial statements. Therefore, the cumulative losses in tax returns are also likely to be significantly different from those reported in the financial statements. In addition, researchers normally use historical data of taxable income to estimate its distribution, which is crucial to the calculation of the SMTR. Given the substantial book-tax differences we document in this section, it is possible that the distribution of taxable income based on the tax returns is also different from that based on financial statements. For these reasons, there is likely to be large measurement errors in the SMTR based on financial statements, which in turn could lead to attenuation biases in estimations.

\subsection{Marginal tax rate versus average tax rate}

Recent studies find that many firms employ the average tax rate to make capital structure decisions rather than the theoretically correct marginal tax rate (Graham 
et al., 2015). One of the arguments put forward is that the average tax rate is perhaps more salient to managers. We investigate this issue in this section. To construct the average effective tax rate $(A E T R)$, we divide corporate tax liability by taxable income. Both the numerator and the denominator of this ratio are obtained from the tax returns. Our empirical analysis in this section is based on positive-profit-only firms, which is not confounded by any measurement error. Based on our calculation, the average effective tax rate for firms in this sample is around $23 \%$.

To ease comparison, we first report in Column 1 of Table 10 the same GMM estimation result as in Column 3 of Table 4, where we use the marginal tax rate as the proxy for tax incentives for using debt. In Column 2, we instead use the $A E T R$ as the proxy. We do not find any significant long-run effect of the AETR on firms' capital structure as the estimated coefficient on the AETR is insignificantly different from zero. In the specification in Column 3, we include both the $M T R$ and the $A E T R$ and interestingly, while we continue to find a significant and positive long-run effect of the $M T R$ on firms' capital structure, we find no effect from the $A E T R$. As robustness checks, we exclude bunching firms around the $£ 10,000$ and $£ 300,000$ thresholds in Columns 4 and 5, and repeat the horse-racing exercise as in Column 3. We continue to find that only the $M T R$ has explanatory power for corporate leverage. These results suggest that firms in our sample use the theoretically correct marginal tax rate for their capital structure decisions rather than the average effective tax rate. Taking together results we obtained in this and previous sections, our estimated tax effects on leverage based on tax returns are strongly consistent with the trade-off theory of capital structure. 


\section{Conclusions}

In this paper, we analyze the effects of corporation tax on companies' capital structure choices using matched confidential tax return data and accounting data for a panel of UK companies during the fiscal years 2001-2009. The first purpose of our study is to estimate the responsiveness of leverage with respect to changes in firms' marginal tax rate, which we measure based on actual firm-level tax returns instead of financial statements. Using a dynamic capital structure model, we find a large and positive long-run effect of taxation on our sample companies' leverage ratios, which is consistent with increasing evidence based on non-tax return data that corporate tax is an important factor in firms' financing decisions. The second purpose of our study is to investigate whether using financial statements alone to infer firms' marginal tax rate might lead to biased estimates. Our analysis documents that tax incentives measured in the absence of tax returns could be plagued with large measurement errors and consequently, the true tax effects on corporate leverage may be more substantial than has been found based on financial statements. One caveat is that our sample firms are private. Measurement errors are likely to be even larger for publicly traded firms (Mills and Newberry, 2001). Therefore, it will be interesting to investigate whether similar measurement problem causes substantial bias in the estimated tax effects on capital structure for listed firms when appropriate tax return data become available. 


\section{References}

[1] Altshuler, R., Auerbach, A., 1990. The significance of tax law asymmetries: An empirical investigation. Quarterly Journal of Economics 105(1), 61-86.

[2] Anderson, T. W., Hsiao, C., 1982. Formulation and estimation of dynamic models using panel data. Journal of Econometrics 18(1), 47-82.

[3] Arellano, M., Bond, S.R., 1991. Some tests of specification for panel data: Monte Carlo evidence and an application to employment equations. Review of Economic Studies 58, 277-297.

[4] Arena, M. P., Kutner, G. W., 2015. Territorial tax system reform and corporate financial policies. Review of Financial Studies 28(8), 2250-2280.

[5] Arena, M. P., Roper, A. H., 2013. The effect of taxes on multinational debt location. Journal of Corporate Finance 16, 637-654.

[6] Barclay, M. J., Heitzman, S. M., Smith, C. W., 2013. Debt and taxes: Evidence from the real estate industry. Journal of Corporate Finance 20, 74-93.

[7] Cloyd, C. B., Pratt, J., Stock, T., 1996. The use of financial accounting choice to support aggressive tax positions: public and private firms. Journal of Accounting Research 34(1), 23-43.

[8] Desai, M. A., 2003. The divergence between book income and tax income, In: Tax Policy and the Economy, Vol. 17. National Bureau of Economic Research.

[9] Desai, M. A., Foley, C. F., Hines Jr., J., 2004. A multinational perspective on capital structure choice and internal capital markets. Journal of Finance 59(6), 2451-2487.

[10] Devereux, M. P., 1989. Tax asymmetries, the cost of capital and investment. Economic Journal 99, 103-112. 
[11] Devereux, M. P., Keen, M., Schiantarelli, F., 1994. Corporation tax asymmetries and investment: Evidence from UK panel data. Journal of Public Economics 53, 395-418.

[12] Doidge, C., Dyck, A., 2015. Taxes and corporate policies: evidence from a quasi natural experiment. Journal of Finance 70(1), 45-89.

[13] Dwenger, N., Steiner, V., 2014. Financial leverage and corporate taxation: Evidence from German corporate tax return data. International Tax and Public Finance 21(1), 1-28.

[14] Faccio, M., Xu, J., 2015. Taxes and capital structure. Journal of Financial and Quantitative Analysis 50(3), 277-300.

[15] Feld, L. P., Heckemeyer, J. H., Overesch, M., 2013. Capital structure choice and company taxation: A meta-study. Journal of Banking and Finance 37, 2850-2866.

[16] Fischer, E. O., Heinkel, R., Zechner, J., 1989. Dynamic capital structure choice: Theory and tests. Journal of Finance 44(1), 19-40.

[17] Flannery, M. J., Hankins, K. W., 2013. Estimating dynamic panel models in corporate finance. Journal of Corporate Finance 19, 1-19.

[18] Flannery, M. J., Rangan, K. P., 2006. Partial adjustment toward target capital structures. Journal of Financial Economics 79(3), 469-506.

[19] Frank, M. Z., Goyal, V. K., 2009. Capital structure decisions: Which factors are reliably important? Financial Management 38(1), 1-37.

[20] Graham, J. R., 1996a. Debt and the marginal tax rate. Journal of Financial Economics 41(1), 41-73.

[21] Graham, J. R., 1996b. Proxies for the corporate marginal tax rate. Journal of Financial Economics 42(2), 187-221. 
[22] Graham, J. R., 2003. Taxes and corporate finance: A review. Journal of Financial Studies 16 (4), 1075-1129.

[23] Graham, J. R., Hanlon, M., Shevlin, T., Shroff, N., 2015. Tax rate and corporate decision making. Mimeo. Available at: http://ssrn.com/abstract=2548641.

[24] Graham, J. R., Mills, L. F., 2008. Using tax returns data to simulate corporate marginal tax rates. Journal of Accounting and Economics 46(2-3), 366-388.

[25] Graham, J. R., Leary, M. T., 2011. A review of capital structure research and directions for the future. Annual Review of Financial Economics 3, 309-345.

[26] Graham, J. R., Leary, M. T., Roberts, M.R., 2014. A century of capital structure: the leveraging of corporate America. Mimeo. Available at: https://papers.ssrn.com/sol3/papers.cfm?abstract_id=2223302.

[27] Gordon, R. H., Lee, Y., 2001. Do taxes affect corporate debt policy? Evidence from U.S. corporate tax return data. Journal of Public Economics 82(2), 195224.

[28] Heider, F., Ljungqvist, A., 2015. As certain as debt and taxes: estimating the tax sensitivity of leverage from state tax changes. Journal of Financial Economics, forthcoming.

[29] Hovakimian, A., Opler, T., Titman, S., 2001. The debt-equity choice. Journal of Financial and Quantitative Analysis 36, 1-24.

[30] Huizinga, H., Laeven, L., Nicodeme, G., 2008. Capital structure and international debt shifting. Journal of Financial. Economics 88, 80-118.

[31] Lemmon, M. L., Roberts, M. R., Zender, J. F., 2008. Back to the beginning: Persistence and the cross-section of corporate capital structure. Journal of Finance 63(4), 1575-1608. 
[32] Longstaff, F. A., Strebulaev, I. A., 2014. Corporate taxes and capital structure: A long-term historical perspective. NBER Working Paper No. 20372.

[33] Manzon Jr., G. B, Plesko, G. A., 2001. The relation between financial and tax reporting measures of income. Working Paper 4332-01, MIT Sloan School of Management.

[34] Maffini, G., Xing, J., Devereux, M. P., 2016. The impact of investment incentives: evidence from UK corporation tax returns. Oxford University Centre for Business Taxation Working Paper No. 16/01.

[35] Miller, M. H., 1977. Debt and Taxes. Journal of Finance 32(2), 261-275.

[36] Mills, L. F., Newberry, K. J., 2001. The influence of tax and non-tax costs on book-tax reporting differences: Public and private firms. Journal of the American Taxation Association 23, 1-19.

[37] Myers, S. C., 1984. The capital structure puzzle. Journal of Finance 39(3), 574-592.

[38] Plesko, G. A., 2000. Book-tax differences and the measurement of corporate income. In: Proceedings of the Ninety-Second Annual Conference on Taxation. Washington, D.C.: National Tax Association.

[39] Roodman, D., 2009. How to do xtabond2: An introduction to difference and system GMM in STATA. The Stata Journal 9(1), 86-136.

[40] Shevlin, T., 1987. Taxes and off-balance sheet financing: Research and development limited partnerships. Accounting Review 62(3), 480-509.

[41] Shevlin, T., 1990. Estimating corporate marginal tax rates with asymmetric tax treatment of gains and losses. Journal of the American Taxation Association 11(2), 51-67. 
[42] Scholes, M. S., Wolfson, M. A., 1992. Tax and business strategy: A planning approach. Prentice-Hall, Englewood Cliffs, NJ.

[43] Weber, C. E., 2014. Toward obtaining a consistent estimate of the elasticity of taxable income using difference-in-differences. Journal of Public Economics 117, 90-103. 
Figure 1: Statutory corporate income tax rate in the UK

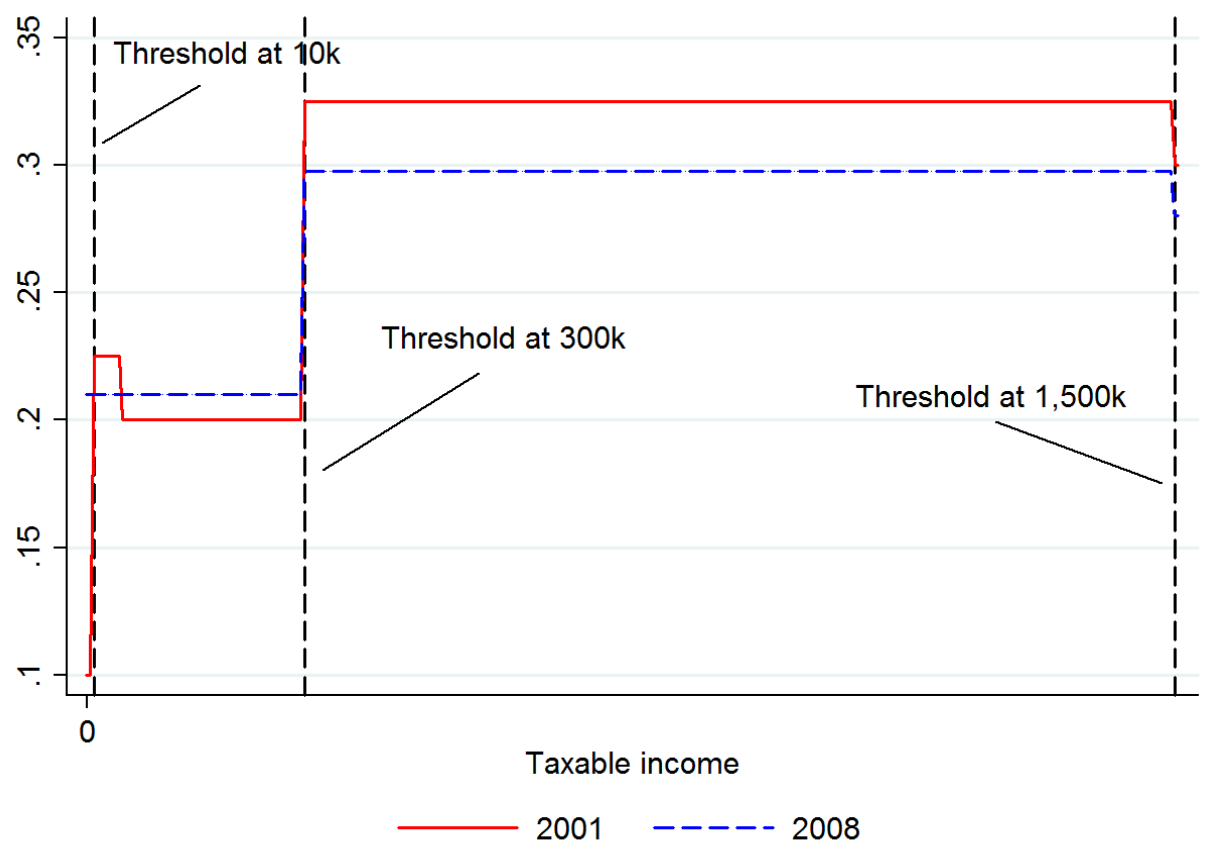

Notes: This figure shows the statutory marginal tax rates for different corporate income tax brackets in the fiscal years 2001 and 2008 in the United Kingdom. We provide more detailed illustration of the statutory marginal tax rates during the entire period 2001-2009 in Appendix A. 
Figure 2: Distribution of marginal tax rates

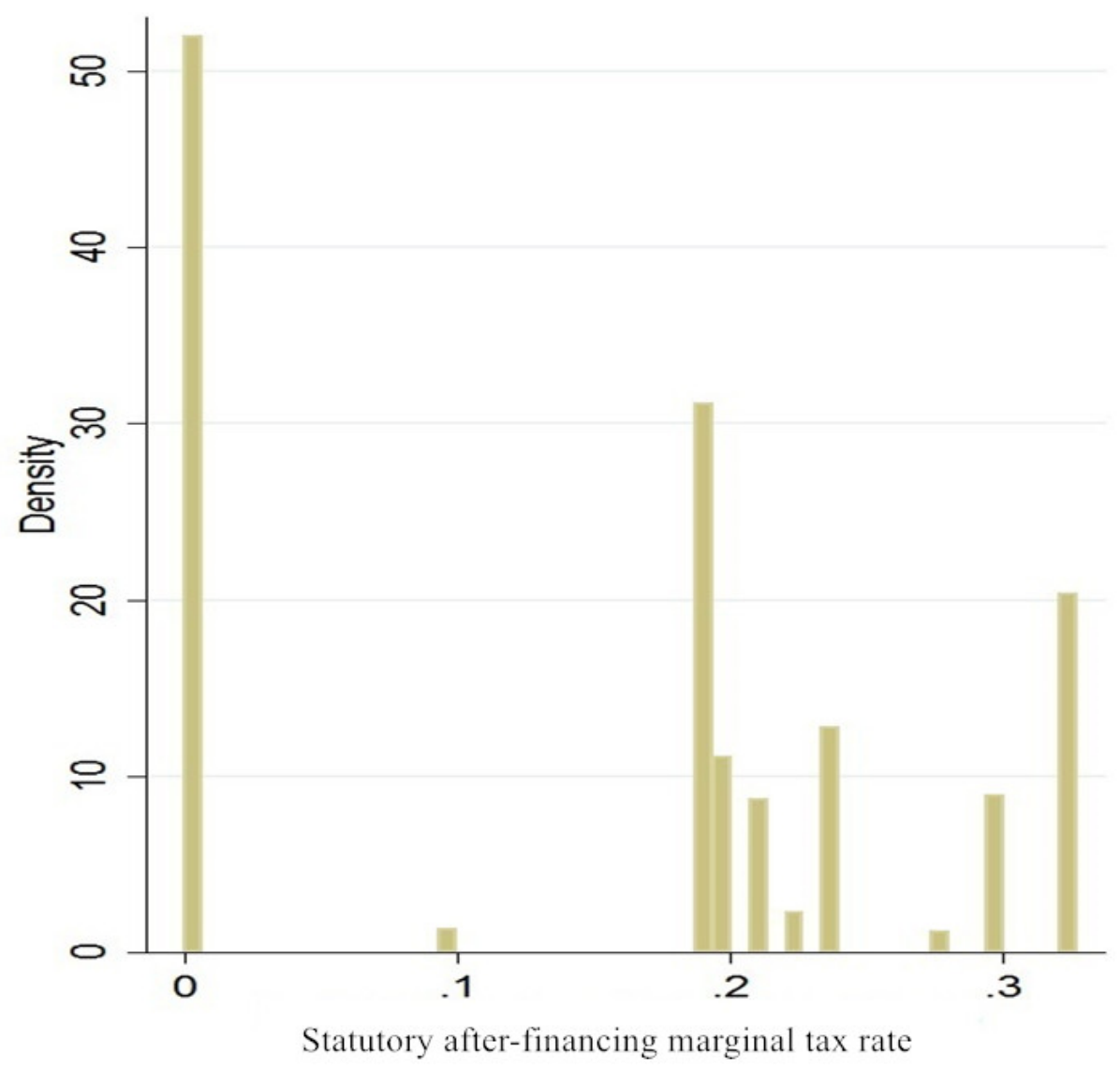

Notes: This figure plots the histogram of the statutory after-financing marginal tax rates for the full sample. 
Figure 3: Distribution of taxable income

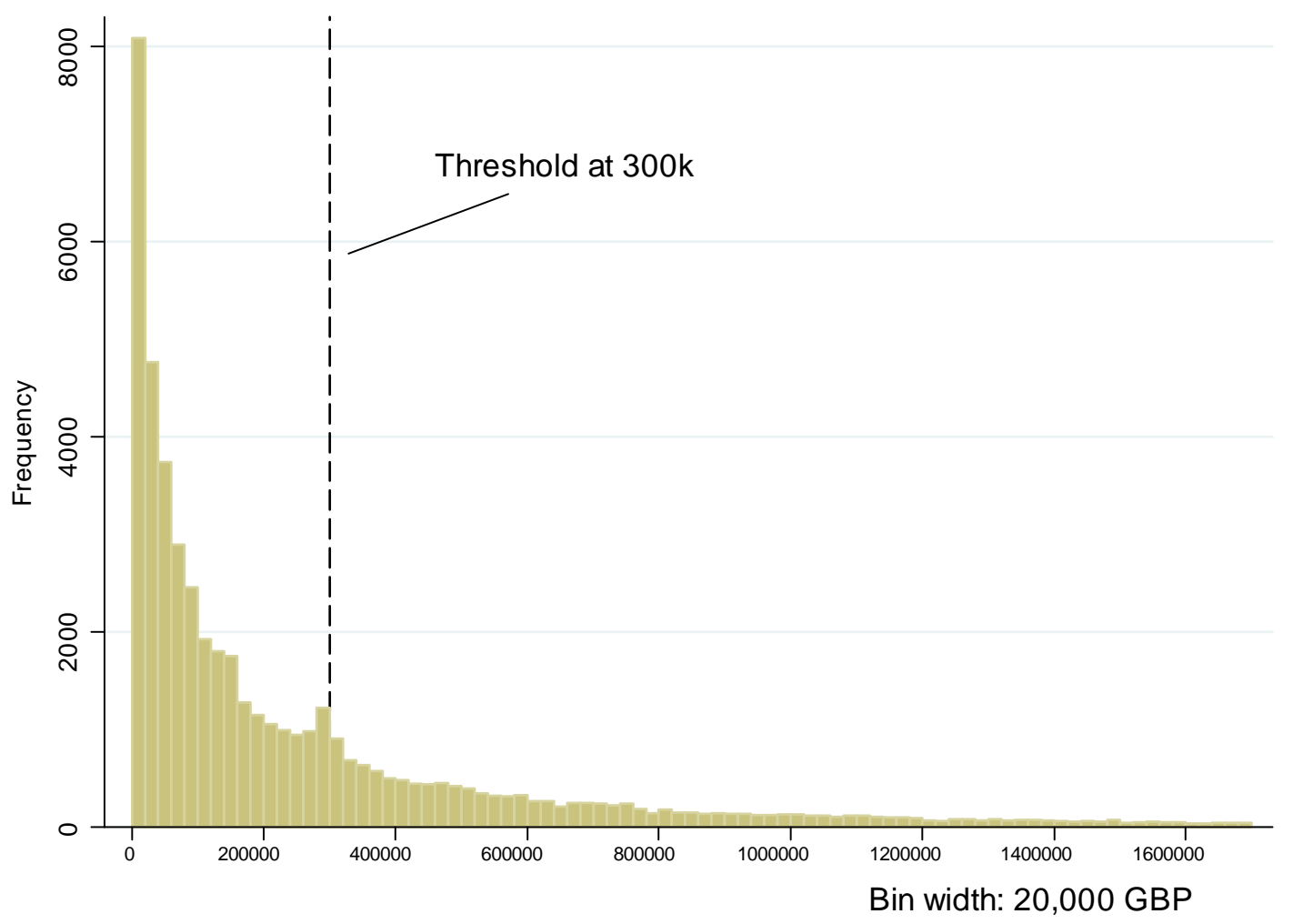

Notes: We provide the histograms of taxable income to illustrate firms' bunching behaviour. This figure shows the entire distribution of taxable income for firms in the positive-profit-only sample. We use $£ 20,000$ as the bin width when we plot this histogram. The figure shows some bunching just below the $£ 300,000$ threshold. 
Figure 4: Distribution of taxable income around 10k, 50k, and 300k
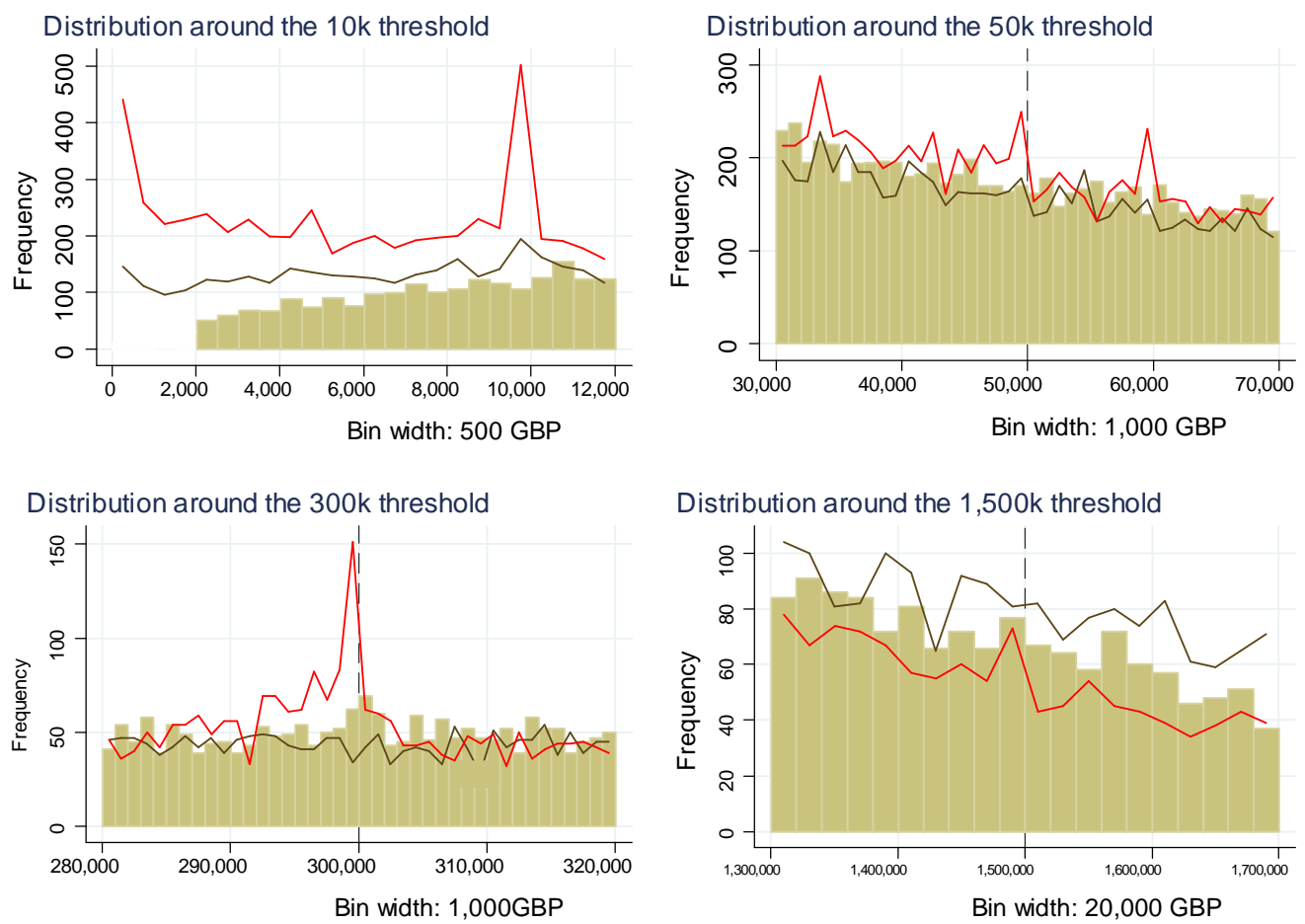

Notes: This figure shows in more details the distribution of taxable income around the $£ 10,000$, $£ 50,000, £ 300,000$, and $£ 1,500,000$ thresholds, respectively. We distinguish between taxable income (red line), before-financing taxable income (brown bars), and taxable income before deducting capital allowances and after financing (black line). This figure reveals some bunching just below the $£ 10,000$ and $£ 300,000$ thresholds, as indicated by the relatively large spikes in the upper-left and the bottom-left panels. 
Table 1: Summary Statistics of Key Variables

A: Excluding loss-making observations (positive-profit-only sample)

\begin{tabular}{lllllll}
\hline \hline Variables & Mean & S.D. & p25 & p50 & p75 & No. obs. \\
\hline Taxable profits & 561,260 & $2,344,378$ & 39,551 & 138,420 & 401,850 & 51,051 \\
After-financing MTR & 0.227 & 0.080 & 0.190 & 0.210 & 0.300 & 51,051 \\
Before-financing MTR & 0.244 & 0.067 & 0.190 & 0.238 & 0.330 & 51,051 \\
Size & 14.590 & 1.639 & 13.430 & 14.826 & 15.651 & 51,051 \\
Tangibility & 0.430 & 0.320 & 0.146 & 0.353 & 0.706 & 51,051 \\
Profitability & 0.086 & 0.104 & 0.026 & 0.055 & 0.108 & 51,051 \\
Leverage & 0.462 & 0.261 & 0.249 & 0.446 & 0.663 & 51,051 \\
\hline
\end{tabular}

B: Loss-making firms

\begin{tabular}{lllllll}
\hline \hline Variables & Mean & S.D. & p25 & p50 & p75 & No. obs. \\
\hline Taxable profits & 121,856 & 845,039 & 0.000 & 0.000 & 17,499 & 42,208 \\
After-financing MTR & 0.070 & 0.109 & 0.000 & 0.000 & 0.190 & 42,208 \\
Perfect-foresight MTR & 0.131 & 0.115 & 0.000 & 0.178 & 0.210 & 42,208 \\
Size & 14.991 & 1.685 & 13.915 & 15.069 & 16.006 & 42,208 \\
Tangibility & 0.461 & 0.319 & 0.172 & 0.423 & 0.745 & 42,208 \\
Profitability & 0.021 & 0.085 & -0.014 & 0.013 & 0.048 & 42,208 \\
Leverage & 0.551 & 0.258 & 0.355 & 0.565 & 0.762 & 42,208 \\
\hline
\end{tabular}

C. Tests of equal means

\begin{tabular}{|c|c|c|c|}
\hline Variables & $\begin{array}{l}\text { Difference in means } \\
\text { (Panel A-Panel B) }\end{array}$ & $\mathrm{T}$ test statistics & Wilcoxon test statistics \\
\hline Taxable profits & 439,404 & $36.620^{* * *}$ & $194.813^{* * *}$ \\
\hline After-financing MTR & 0.157 & $253.562^{* * *}$ & $178.342^{* * *}$ \\
\hline Size & -0.400 & $-36.645^{* * *}$ & $-33.586^{* * *}$ \\
\hline Tangibility & -0.031 & $-14.775^{* * *}$ & $-14.455^{* * *}$ \\
\hline Profitability & 0.065 & $102.939 * * *$ & $126.548^{* * *}$ \\
\hline Leverage & -0.089 & $-52.276^{* * *}$ & $-51.884^{* * *}$ \\
\hline
\end{tabular}

Notes: Panel A summarizes the statistics of key variables for firms in the positiveprofit-only sample, which consists of 9,439 companies and 51,051 observations. Panel B summarize the statistics of key variables for firms that ever experienced losses, which consists of 42,208 observations. Definitions of these key variables are provided in Appendix B. It is worth noting that we do not observe the actual level of losses for loss-making firmyear observations. Taxable profits are recorded as 0 in the tax returns for loss-making firms. As a result, we cannot compute the before-financing MTR in Panel B. In Panel $\mathrm{C}$, we report results from the t-test and Wilcoxon test of the null hypothesis that the two groups of firms have equal means of taxable profits, the after-financing MTR, size, tangibility, profitability, and leverage. The stars indicate the significance level of the $\mathrm{T}$ test and the Wicoxon test statistics, ${ }^{* * *} \mathrm{p}<0.01,{ }^{* *} \mathrm{p}<0.05,{ }^{*} \mathrm{p}<0.1$. 
Table 2: Transitional Probability Matrix of Taxable Profits from Year $t-1$ to Year $t$

Positive-profit-only sample

\begin{tabular}{cl|ccc}
\hline \hline & \multicolumn{3}{|c}{$t$} \\
& Taxable Profits & $£ 0-50,000$ & $£ 50,000-300,000$ & $>£ 300,000$ \\
\hline \multirow{2}{*}{$t-1$} & $£ 0-50,000$ & $73.68 \%$ & $23.04 \%$ & $3.28 \%$ \\
& $£ 50,000-300,000$ & $14.05 \%$ & $68.25 \%$ & $17.7 \%$ \\
& $>£ 300,000$ & $2.6 \%$ & $17.47 \%$ & $79.93 \%$ \\
\hline
\end{tabular}

Full sample

\begin{tabular}{|c|c|c|c|c|c|}
\hline & & & & $t$ & \\
\hline & Taxable Profits & Loss & $£ 0-50,000$ & $£ 50,000-300,000$ & $>£ 300,000$ \\
\hline & Loss & $69.57 \%$ & $16.04 \%$ & $9.62 \%$ & $4.77 \%$ \\
\hline$t-1$ & $£ 0-50,000$ & $19.98 \%$ & $59.02 \%$ & $18.30 \%$ & $2.70 \%$ \\
\hline & $£ 50,000-300,000$ & $11.55 \%$ & $13.81 \%$ & $58.96 \%$ & $15.68 \%$ \\
\hline & $>£ 300,000$ & $8.79 \%$ & $2.89 \%$ & $16.40 \%$ & $71.93 \%$ \\
\hline
\end{tabular}

Notes: Panel A reports the transitional probability of taxable profits from one year to the next for firms in the positive-profit-only sample. For confidentiality reason, we groups observations into three tax brackets: £0-50,000, £50,000-300,000, >£300,000. Each number in the diagonal indicates the probability of the firm stays in the same tax bracket from year $t-1$ to year $t$. Each off-diagonal number indicates the probability of the firm switching from one tax bracket to a different one from year $t-1$ to year $t$. Panel B reports the transitional probability of taxable profits for firms in the full sample, including those making taxable losses. 
Table 3: Number of Tax Status Changes within Companies

Positive-profit-only sample: Total number of tax status changes

\begin{tabular}{lcccc}
\hline \hline No. of changes & No. of companies & \% total companies & No. of obs & $\%$ total obs \\
\hline 0 & 2,385 & $25.30 \%$ & 11,946 & $23.40 \%$ \\
1 & 2,618 & $27.70 \%$ & 13,419 & $26.29 \%$ \\
2 & 2,450 & $26.00 \%$ & 12,987 & $25.44 \%$ \\
$\geqq 3$ & 1,986 & $21.10 \%$ & 12,699 & $24.88 \%$ \\
\hline Total & 9,439 & $100 \%$ & 51,051 & $100 \%$
\end{tabular}

Positive-profit-only sample: Total number of moving in and out of the $£ 300,000$ tax bracket

\begin{tabular}{lcccc}
\hline \hline No. of changes & No. of companies & \% total companies & No. of obs & \% total obs \\
\hline 0 & 6,167 & $65.34 \%$ & 32,001 & $62.68 \%$ \\
1 & 1,506 & $15.96 \%$ & 8,173 & $16.01 \%$ \\
2 & 1,145 & $12.13 \%$ & 6,508 & $12.75 \%$ \\
$\geqq 3$ & 621 & $6.58 \%$ & 4,369 & $8.56 \%$ \\
\hline Total & 9,439 & $100 \%$ & 51,051 & $100 \%$ \\
\hline
\end{tabular}

Full sample: Total number of tax status changes

\begin{tabular}{lcccc}
\hline \hline No. of changes & No. of companies & \% total companies & No. of obs & $\%$ total obs \\
\hline 0 & 3,308 & $20.50 \%$ & 16,882 & $18.10 \%$ \\
1 & 3,449 & $21.40 \%$ & 17,836 & $19.13 \%$ \\
2 & 4,091 & $25.40 \%$ & 22,274 & $23.88 \%$ \\
$\geqq 3$ & 5,276 & $32.72 \%$ & 36,267 & $38.89 \%$ \\
\hline Total & 16,124 & $100 \%$ & 93,259 & $100 \%$ \\
\hline
\end{tabular}

Full sample: Total number of moving in and out of taxable losses

\begin{tabular}{lcccc}
\hline \hline No. of changes & No. of companies & \% total companies & No. of obs & \% total obs \\
\hline 0 & 8,063 & $50.01 \%$ & 44,041 & $47.22 \%$ \\
1 & 3,977 & $24.67 \%$ & 22,414 & $24.03 \%$ \\
2 & 2,700 & $16.75 \%$ & 16,705 & $17.91 \%$ \\
$\geqq 3$ & 1,384 & $8.58 \%$ & 10,099 & $10.83 \%$ \\
\hline Total & 9,439 & $100 \%$ & 93,259 & $100 \%$
\end{tabular}

Notes: This table shows information on the number of times companies changed tax brackets. For both samples, we indicate how many companies do not change tax brackets at all, or change once, twice or more than twice. 
Table 4: Estimated Tax Effects on Leverage

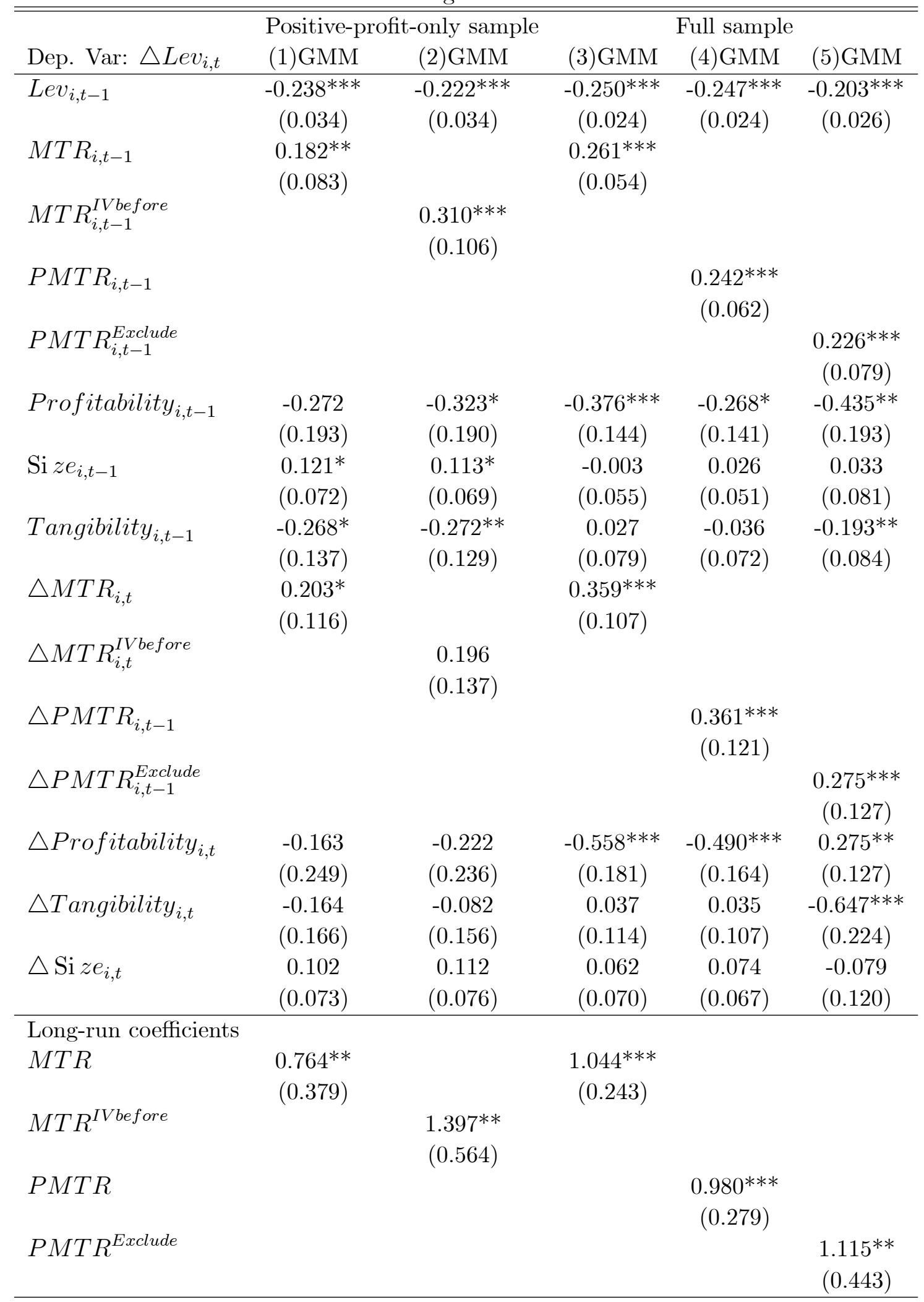


Table 4 continued

\begin{tabular}{lccccc}
\hline & $(1)$ & $(2)$ & $(3)$ & $(4)$ & $(5)$ \\
\hline Hansen test & 0.754 & 0.713 & 0.121 & 0.079 & 0.607 \\
AR(1) & 0.000 & 0.000 & 0.000 & 0.000 & 0.000 \\
AR(2) & 0.001 & 0.001 & 0.003 & 0.002 & 0.000 \\
AR(3) & 0.620 & 0.728 & 0.888 & 0.592 & 0.330 \\
Year dummies & Yes & Yes & Yes & Yes & Yes \\
Company FE & Yes & Yes & Yes & Yes & Yes \\
No. of groups & 9,439 & 9,439 & 16,124 & 16,124 & 15,158 \\
No. of obs. & 32,173 & 32,173 & 61,011 & 61,011 & 50,906 \\
\hline
\end{tabular}

Notes: We report the difference GMM estimation results based on Equation (7). We apply the difference GMM estimator using the instrumenting strategy as explained in Section 4. $\operatorname{Lev}_{i, t}$ is the firm $i$ 's leverage ratio in year $t$, and $M T R_{i, t}$ is the statutory marginal tax rate that firm $i$ faced in year $t$. We use the positive-profit-only sample in Columns 1-2. In Columns 1, we use the lags of the $M T R$, the lags of leverage, profitability, tangibility and firm size (dated at t-3 and t- 4 , similarly below) as a set of instruments for current MTR and other endogeneous variables in the difference GMM estimations. In Columns 2, we include the lags of the before-financing $M T R$, rather than the lags of the after-financing $M T R$, in the set of instruments. We estimate using the full sample in Columns 3-5. In Columns 3, we use $M T R$ as a proxy for the corporate tax incentives for using debt. In Columns 4-5, we use the perfect-foresight marginal tax rate $(P M T R)$ as a proxy for the corporate tax incentives instead. In Column 3 (or 4 and 5), we use lags of $M T R$ (or PMTR), lags of profitability, tangibility and size as instruments. In Column 5 , we drop the first or the last observation for each company if it reported a taxable loss in that year. We also report the estimated long-run coefficients on explanatory variables. In this and subsequent tables, the long-run coefficients are calculated as follows. Based on Equation 7, the long-run effect of the corporate tax rate on leverage is given by $\left(\beta_{1}+\beta_{2}\right) /\left(1-\alpha_{1}\right)$, where $\beta_{1}+\beta_{2}$ is the estimated coefficient on the lagged MTR and $\alpha_{1}$ is the estimated coefficient on the lagged leverage. The long-run effect of other control variables are calculated accordingly. We use the Stata command "nlcom" to calculate the long-run coefficients and the associated standard errors. Standard errors are reported in parentheses, and are robust and clustered by firms. ${ }^{* * *} \mathrm{p}<0.01,{ }^{* *} \mathrm{p}<0.05,{ }^{*} \mathrm{p}<0.1$. 
Table 5: Excluding bunching firms

\begin{tabular}{|c|c|c|c|c|}
\hline \multirow[b]{2}{*}{ Dep. Var: $\triangle L e v_{i, t}$} & \multicolumn{2}{|c|}{ Positive-profit-only sample } & \multicolumn{2}{|c|}{ Full sample } \\
\hline & (1)GMM & (2)GMM & (3) GMM & (4)GMM \\
\hline$L e v_{i, t-1}$ & $\begin{array}{c}-0.243^{* * *} \\
(0.035)\end{array}$ & $\begin{array}{c}-0.227^{* * *} \\
(0.036)\end{array}$ & $\begin{array}{c}-0.242^{* * *} \\
(0.026)\end{array}$ & $\begin{array}{c}-0.238^{* * *} \\
(0.025)\end{array}$ \\
\hline$M T R_{i, t-1}$ & $\begin{array}{c}0.169^{* *} \\
(0.085)\end{array}$ & & $\begin{array}{c}0.248^{* *} \\
(0.058)\end{array}$ & \\
\hline$M T R_{i, t-1}^{I V b e f o r e}$ & & $\begin{array}{c}0.307^{* * *} \\
(0.108)\end{array}$ & & \\
\hline$P M T R_{i, t-1}$ & & & & $\begin{array}{c}0.218^{* *} \\
(0.066)\end{array}$ \\
\hline$\Delta M T R_{i, t}$ & $\begin{array}{c}0.169 \\
(0.114)\end{array}$ & & $\begin{array}{c}0.337^{* * *} \\
(0.111)\end{array}$ & \\
\hline$\Delta M T R_{i, t}^{I V b e f o r e}$ & & $\begin{array}{c}0.192 \\
(0.134)\end{array}$ & & \\
\hline$\triangle P M T R_{i, t}$ & & & & $\begin{array}{c}0.313^{* *} \\
(0.129)\end{array}$ \\
\hline Long-run coefficients & & & & \\
\hline$M T R$ & $\begin{array}{l}0.698^{*} \\
(0.372)\end{array}$ & & $\begin{array}{c}1.026^{* * *} \\
(0.267)\end{array}$ & \\
\hline$M T R^{I V b e f o r e}$ & & $\begin{array}{c}1.357^{* *} \\
(0.560)\end{array}$ & & \\
\hline$P M T R$ & & & & $\begin{array}{c}0.915^{* * *} \\
(0.307)\end{array}$ \\
\hline Control variables & Yes & Yes & Yes & Yes \\
\hline Year dummies & Yes & Yes & Yes & Yes \\
\hline Company FE & Yes & Yes & Yes & Yes \\
\hline Hansen test & 0.613 & 0.473 & 0.154 & 0.063 \\
\hline No. of groups & 9,199 & 9,199 & 15,856 & 15,856 \\
\hline No. of obs. & 30,185 & 30,185 & 58,148 & 58,148 \\
\hline
\end{tabular}

Notes: We exclude observations bunching below the $£ 10,000$ and $£ 300,000$ thresholds and re-estimate based on Equation (7). We report the difference GMM estimation results based on the samples excluding bunching firms. In this and all subsequent tables, we firstdifference Equation (7) to get rid of the firm-specific fixed effects. Estimation in Columns 1 and 2 are based on the positive-profit-only sample. We use the lags of the MTR,the lags of leverage, profitability, tangibility and firm size as a set of instruments in Column 1 , and we include the lags of the before-financing $M T R$ in the set of instruments in Column 2. We report the difference GMM estimation results based on the full sample in Columns 3-4. Short-run dynamics as specified in Equation (7) are included in all the columns. We include firm size, tangibility and profitability in each column but coefficients on these variables are not reported for brevity. Standard errors are reported in parentheses, and are robust and clustered by firms. ${ }^{* * *} \mathrm{p}<0.01,{ }^{* *} \mathrm{p}<0.05,{ }^{*} \mathrm{p}<0.1$. 
Table 6: Is the Effect of Taxation on Firms' Capital Structure Asymmetric?

\begin{tabular}{|c|c|c|c|}
\hline Dep. Var & Positive-profit-only sample & \multicolumn{2}{|c|}{ Full sample } \\
\hline$\triangle L e v_{i, t}$ & $(1)$ & $(2)$ & (3) \\
\hline$L e v_{i, t-1}$ & $\begin{array}{c}-0.232^{* * *} \\
(0.034)\end{array}$ & $\begin{array}{c}-0.264^{* * *} \\
(0.026)\end{array}$ & $\begin{array}{c}-0.262^{* * *} \\
(0.025)\end{array}$ \\
\hline$M T R_{i, t-1}$ & $\begin{array}{l}0.173^{*} \\
(0.089)\end{array}$ & $\begin{array}{c}0.282^{* * *} \\
(0.060)\end{array}$ & \\
\hline Increase $_{i, t} \times M T R_{i, t-1}$ & $\begin{array}{l}-0.038 \\
(0.041)\end{array}$ & $\begin{array}{c}-0.102^{* *} \\
(0.049)\end{array}$ & \\
\hline$P M T R_{i, t-1}$ & & & $\begin{array}{c}0.266^{* * *} \\
(0.064)\end{array}$ \\
\hline Increase $_{i, t} \times P M T R_{i, t-1}$ & & & $\begin{array}{c}-0.098^{* *} \\
(0.048)\end{array}$ \\
\hline$\triangle M T R_{i, t}$ & $\begin{array}{c}0.326 \\
(0.229)\end{array}$ & $\begin{array}{c}0.585^{* * *} \\
(0.211)\end{array}$ & \\
\hline Increase $_{i, t} \times \triangle M T R_{i, t}$ & $\begin{array}{l}-0.121 \\
(0.282)\end{array}$ & $\begin{array}{l}-0.216 \\
(0.215)\end{array}$ & \\
\hline$\triangle P M T R_{i, t}$ & & & $\begin{array}{c}0.807^{* * *} \\
(0.247)\end{array}$ \\
\hline Increase $_{i, t} \times \triangle P M T R_{i, t}$ & & & $\begin{array}{l}-0.478^{*} \\
(0.260)\end{array}$ \\
\hline Control variables & Yes & Yes & Yes \\
\hline Year dummies & Yes & Yes & Yes \\
\hline Company FE & Yes & Yes & Yes \\
\hline Hansen test & 0.597 & 0.319 & 0.173 \\
\hline No. of groups & 9,439 & 16,124 & 16,124 \\
\hline No. of obs. & 32,173 & 61,011 & 61,011 \\
\hline
\end{tabular}

Notes: In this table, we report the difference GMM estimation results regarding the asymmetric tax effects on leverage. In Columns 1 and 2, we estimate the following model:

$$
\begin{aligned}
\triangle \text { Lev }_{i, t}= & \alpha_{0}+\left(\alpha_{1}-1\right) \operatorname{Lev}_{i, t-1}+\left(\beta_{1}+\beta_{2}\right) M T R_{i, t-1}+\beta_{3} \text { Increase }_{i, t} \times M T R_{i, t-1} \\
& +\left(\gamma_{1}+\gamma_{2}\right) Z_{i, t-1}+\beta_{1} \triangle M T R_{i, t}+\beta_{4} \text { Increase }_{i, t} \times \triangle M T R_{i, t} \\
& +\gamma_{1} \triangle Z_{i, t}+\mu_{i}+\theta_{t}+\epsilon_{i, t}
\end{aligned}
$$

Increase $_{i, t}$ is a dummy variable that equals 1 if firm $i$ 's marginal tax rate based on tax returns increases from year $t-1$ to year $t$. In Column 3 , we use the perfect-forsight MTR to proxy for the tax incentive. We use the third and fourth lags of the explanatory variables as instruments. Short-run dynamics are included in all the columns. We include firm size, tangibility and profitability in each column. Standard errors are reported in parentheses, and are robust and clustered by firms. ${ }^{* * *} \mathrm{p}<0.01,{ }^{* *} \mathrm{p}<0.05,{ }^{*} \mathrm{p}<0.1$. 
Table 7: Domestic standalone companies versus multinational companies (GMM estimation results)

\begin{tabular}{|c|c|c|c|c|}
\hline \multirow{3}{*}{$\begin{array}{l}\text { Dep. Var } \\
\triangle E X L e v_{i, t}\end{array}$} & \multicolumn{2}{|c|}{ Positive-profit-only } & \multicolumn{2}{|l|}{ Full sample } \\
\hline & $(1)$ & $(2)$ & $(3)$ & (4) \\
\hline & $\begin{array}{l}\text { Domestic } \\
\text { stand alone }\end{array}$ & Part of MNCs & $\begin{array}{c}\text { Domestic } \\
\text { stand alone }\end{array}$ & Part of MNCs \\
\hline $\operatorname{Lev}_{i, t-1}$ & $\begin{array}{c}-0.262^{* * *} \\
(0.040)\end{array}$ & $\begin{array}{c}-0.336^{* * *} \\
(0.072)\end{array}$ & $\begin{array}{c}-0.285^{* * *} \\
(0.040)\end{array}$ & $\begin{array}{c}-0.490^{* * *} \\
(0.067)\end{array}$ \\
\hline$M T R_{i, t-1}$ & $\begin{array}{c}0.262^{* *} \\
(0.115)\end{array}$ & $\begin{array}{c}0.371^{* *} \\
(0.161)\end{array}$ & $\begin{array}{c}0.262^{* * *} \\
(0.079)\end{array}$ & $\begin{array}{l}0.140^{*} \\
(0.077)\end{array}$ \\
\hline$\triangle M T R_{i, t}$ & $\begin{array}{l}-0.047 \\
(0.146)\end{array}$ & $\begin{array}{c}0.241 \\
(0.213)\end{array}$ & $\begin{array}{c}0.494^{* * *} \\
(0.145)\end{array}$ & $\begin{array}{c}0.264^{* *} \\
(0.110)\end{array}$ \\
\hline $\begin{array}{l}\text { Long-run coefficients } \\
M T R\end{array}$ & $\begin{array}{l}1.000^{* *} \\
(0.498)\end{array}$ & $\begin{array}{l}1.104^{* *} \\
(0.545)\end{array}$ & $\begin{array}{c}0.920^{* * *} \\
(0.319)\end{array}$ & $\begin{array}{l}0.285^{*} \\
(0.167)\end{array}$ \\
\hline Control variables & Yes & Yes & Yes & Yes \\
\hline Year dummies & Yes & Yes & Yes & Yes \\
\hline Company FE & Yes & Yes & Yes & Yes \\
\hline Hansen test & 0.295 & 0.594 & 0.067 & 0.060 \\
\hline No. of groups & 6,466 & 2,458 & 10,545 & 4,597 \\
\hline No. of obs. & 21,713 & 8,669 & 38,888 & 18,214 \\
\hline
\end{tabular}

Notes: We report the difference GMM estimation results based on Equation (7) where the dependent variable $\triangle E X L e v$ is the firms' external leverage. In Columns 1 and 3 , we run the difference GMM estimations using the sub-sample of domestic stand-alone firms. In Columns 2 and 4, we run the difference GMM estimations using the sub-sample of firms that are part of a multinational group. We include the third and the fourth lags of leverage, after-financing marginal tax rate and other control variables in the set of instruments. Short-run dynamics are included in all the columns. We also include firm size, tangibility and profitability in each column. Standard errors are reported in parentheses, and are robust and clustered by firms. ${ }^{* * *} \mathrm{p}<0.01,{ }^{* *} \mathrm{p}<0.05,{ }^{*} \mathrm{p}<0.1$. 
Table 8: Correspondence between Tax Returns and Accounting Data in terms of Companies' Taxable Profits

\section{Panel A: Taxable profits in the tax returns versus estimated taxable profits using financial statements}

Positive-profit-only sample

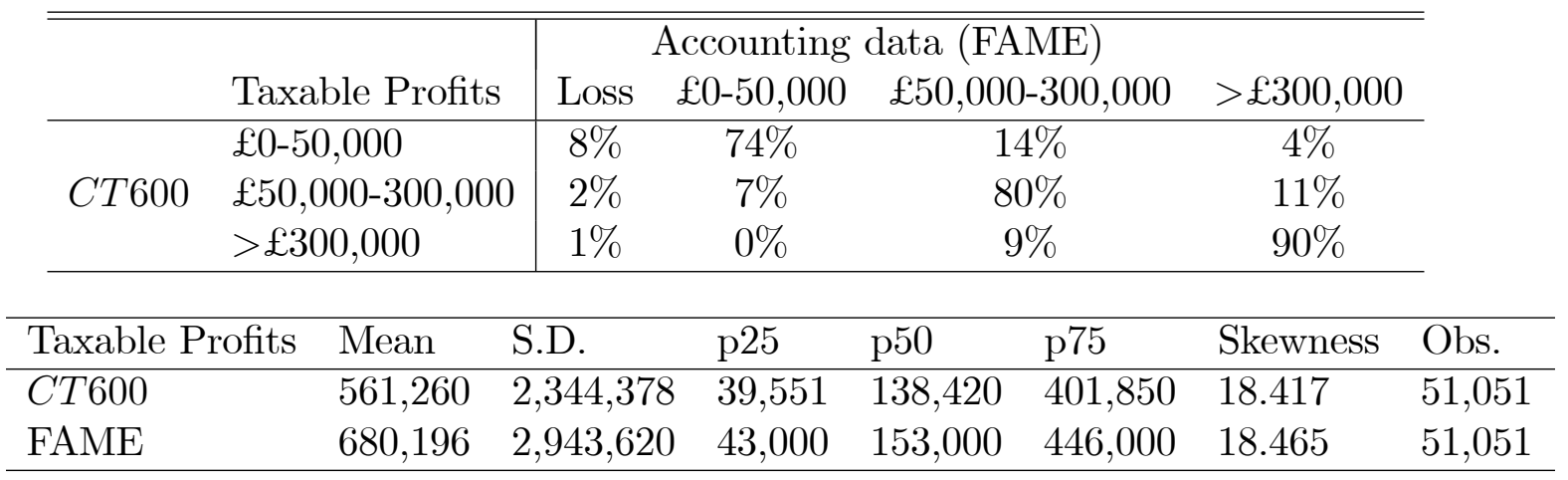

Full sample

\begin{tabular}{|c|c|c|c|c|c|c|c|}
\hline & \multirow[b]{2}{*}{ Taxable Profits } & \multicolumn{4}{|c|}{ Accounting data (FAME) } & \multirow[b]{2}{*}{$>£ 300,000$} & \\
\hline & & Loss & $£ 0-50,000$ & $£ 50,0$ & $000-300,000$ & & \\
\hline \multirow{4}{*}{ CT600 } & Loss & $49.2 \%$ & $16.5 \%$ & & $17.6 \%$ & $16.7 \%$ & \\
\hline & $£ 0-50,000$ & $10.4 \%$ & $66.7 \%$ & & $17.1 \%$ & $5.9 \%$ & \\
\hline & $£ 50,000-300,000$ & $2.4 \%$ & $7.1 \%$ & & $78 \%$ & $12.5 \%$ & \\
\hline & $>£ 300,000$ & $1.1 \%$ & $0.3 \%$ & & $8.7 \%$ & $90 \%$ & \\
\hline Taxable Profits & Mean & S.D. & $\mathrm{p} 25$ & p50 & $\mathrm{p} 75$ & Skewness & Obs. \\
\hline \multirow{2}{*}{$\begin{array}{l}C T 600 \\
\text { FAME }\end{array}$} & 362,205 & $1,837,828$ & 0 & 40,580 & 230,620 & 22.264 & 93,259 \\
\hline & 610,010 & $2,780,371$ & 12,000 & 93,000 & 350,000 & 18.081 & 93,259 \\
\hline
\end{tabular}

Notes: We observe companies' taxable profits in the tax returns and estimate their taxable profits based on the financial statements. We report the mean and standard deviations (S.D.) of the two types of taxable profits, and we also report the value of taxable profits at the $25 \mathrm{th}, 50 \mathrm{th}$, and $75 \mathrm{th}$ percentile of the distribution. Skewness of the distribution of the taxable profits is also reported. We calculate the correspondence of tax brackets between the tax returns and the accounting data. For confidentiality reason, we group the tax brackets $£ 0-10,000$ and $£ 10,000-50,000$ together. For firms in each tax bracket according to the tax returns (CT600), we calculate the percentages of these firms in different tax brackets according to the estimated taxable profits based on firms' financial statements. 
Panel B: Correlation between Different Tax Incentive Measures Based on Tax Returns and Financial Statements

\begin{tabular}{|c|c|c|c|c|}
\hline \multicolumn{5}{|c|}{ Positive-profit-only sample } \\
\hline & MTR & $M T R_{\text {before }}$ & $M T R^{F S}$ & $M T R_{\text {before }}^{F S}$ \\
\hline$M T R$ & 1 & & & \\
\hline$M T R_{\text {before }}$ & 0.703 & 1 & & \\
\hline$M T R^{F S}$ & 0.688 & 0.594 & 1 & \\
\hline$M T R_{\text {before }}^{F S}$ & 0.618 & 0.737 & 0.773 & 1 \\
\hline \multicolumn{5}{|c|}{ Full sample } \\
\hline & $M T R$ & $M T R^{F S}$ & $P M T R$ & $P M T R^{F S}$ \\
\hline$M T R$ & 1 & & & \\
\hline$M T R^{F S}$ & 0.600 & 1 & & \\
\hline$P M T R$ & 0.807 & 0.528 & 1 & \\
\hline$P M T R^{F S}$ & 0.456 & 0.758 & 0.520 & 1 \\
\hline
\end{tabular}

Notes: In this table, we calculate the partial correlations between different tax incentive measures calculated based on tax returns and financial statements. $M T R$ is the after-financing marginal tax rate, calculated based on companies' taxable profits in the tax returns. $M T R_{\text {before }}$ is the before-financing marginal tax rate, calculated based on companies' taxable profits reported in the tax returns plus interest expenses. $M T R^{F S}$ is the after-financing marginal tax rate calculated based on the estimated taxable profits according to companies' financial statement. $M T R_{\text {before }}^{F S}$ is the before-financing marginal tax rate calculated based on the estimated taxable profits before interest deduction according to financial statements. $P M T R$ is the perfect-foresight marginal tax rate calculated based on tax returns, and $P M T R^{F S}$ is the corresponding measure based on financial statements. 
Table 9: Does marginal tax rate measured based on tax returns better capture tax incentives for borrowing?

\begin{tabular}{|c|c|c|c|c|c|c|c|c|}
\hline \multirow[t]{2}{*}{ Panel A } & \multicolumn{4}{|c|}{ Positive-profit-only sample } & \multicolumn{4}{|c|}{ Full sample } \\
\hline & (1) & (2) & (3) & $(4)$ & $(5)$ & $(6)$ & (7) & (8) \\
\hline $\operatorname{Lev}_{i, t-1}$ & $\begin{array}{c}-0.238^{* * *} \\
(0.034)\end{array}$ & $\begin{array}{c}-0.248^{* * *} \\
(0.034)\end{array}$ & $\begin{array}{c}-0.222^{* * *} \\
(0.034)\end{array}$ & $\begin{array}{c}-0.241^{* * *} \\
(0.035)\end{array}$ & $\begin{array}{c}-0.209^{* * *} \\
(0.025)\end{array}$ & $\begin{array}{c}-0.216^{* * *} \\
(0.025)\end{array}$ & $\begin{array}{c}-0.203^{* * *} \\
(0.026)\end{array}$ & $\begin{array}{c}-0.211^{* * *} \\
(0.026)\end{array}$ \\
\hline$M T R_{i, t-1}$ & $\begin{array}{c}0.182^{* *} \\
(0.083)\end{array}$ & & & & $\begin{array}{c}0.136^{* *} \\
(0.054)\end{array}$ & & & \\
\hline$M T R_{i, t-1}^{F S}$ & & $\begin{array}{c}0.016 \\
(0.113)\end{array}$ & & & & $\begin{array}{c}0.051 \\
(0.085)\end{array}$ & & \\
\hline$M T R_{i, t-1}^{I V b e f o r e}$ & & & $\begin{array}{c}0.310^{* * *} \\
(0.106)\end{array}$ & & & & & \\
\hline$M T R_{i, t-1}^{F S_{-1} \text { IVbefore }}$ & & & & $\begin{array}{c}0.120 \\
(0.141)\end{array}$ & & & & \\
\hline$P M T R_{i, t-1}$ & & & & & & & $\begin{array}{c}0.226^{* * *} \\
(0.079)\end{array}$ & \\
\hline$P M T R_{i, t-1}^{F S}$ & & & & & & & & $\begin{array}{l}0.202^{*} \\
(0.114)\end{array}$ \\
\hline$\Delta M T R_{i, t}$ & $\begin{array}{l}0.203^{*} \\
(0.116)\end{array}$ & & & & $\begin{array}{r}0.226^{* *} \\
(0.101)\end{array}$ & & & \\
\hline$\Delta M T R_{i, t}^{F S}$ & & $\begin{array}{l}-0.116 \\
(0.148)\end{array}$ & & & & $\begin{array}{c}0.015 \\
(0.102)\end{array}$ & & \\
\hline$\Delta M T R_{i, t}^{I V b e f o r e}$ & & & $\begin{array}{c}0.196 \\
(0.137)\end{array}$ & & & & & \\
\hline$\Delta M T R_{i, t}^{F S_{-} I \text { IVbefore }}$ & & & & $\begin{array}{l}-0.110 \\
(0.177)\end{array}$ & & & & \\
\hline$\Delta P M T R_{i, t}$ & & & & & & & $\begin{array}{c}0.275^{* *} \\
(0.127)\end{array}$ & \\
\hline$\Delta P M T R_{i, t}^{F S}$ & & & & & & & & $\begin{array}{c}0.410^{* * *} \\
(0.159)\end{array}$ \\
\hline Long-run coefficients & & & & & & & & \\
\hline$M T R$ & $\begin{array}{c}0.764^{* *} \\
(0.379)\end{array}$ & & & & $\begin{array}{c}0.651^{* *} \\
(0.284)\end{array}$ & & & \\
\hline$M T R^{F S}$ & & $\begin{array}{c}0.063 \\
(0.455)\end{array}$ & & & & $\begin{array}{c}0.235 \\
(0.400)\end{array}$ & & \\
\hline$M T R^{I V b e f o r e}$ & & & $\begin{array}{l}1.397^{* *} \\
(0.564)\end{array}$ & & & & & \\
\hline$M T R^{F S_{-} I V b e f o r e}$ & & & & $\begin{array}{c}0.499 \\
(0.603)\end{array}$ & & & & \\
\hline$P M T R$ & & & & & & & $\begin{array}{l}1.115^{* *} \\
(0.443)\end{array}$ & \\
\hline$P M T R^{F S}$ & & & & & & & & $\begin{array}{c}0.958 \\
(0.601)\end{array}$ \\
\hline
\end{tabular}


Table 9 continued

\begin{tabular}{lcccccccc}
\hline \multirow{2}{*}{ Control variables } & $(1)$ & $(2)$ & $(3)$ & $(4)$ & $(5)$ & $(6)$ & $(7)$ & $(8)$ \\
Year FE & Yes & Yes & Yes & Yes & Yes & Yes & Yes & Yes \\
Company FE & Yes & Yes & Yes & Yes & Yes & Yes & Yes & Yes \\
Hansen test & 0.754 & 0.535 & 0.713 & 0.702 & 0.383 & 0.393 & 0.607 & 0.567 \\
No. of groups & 9,439 & 9,439 & 9,439 & 9,439 & 15,158 & 15,158 & 15,158 & 15,158 \\
No. of obs. & 32,173 & 32,173 & 32,173 & 32,173 & 50,906 & 50,906 & 50,906 & 50,906 \\
\hline
\end{tabular}

Notes: We report the difference GMM estimation results of Equation (7) where we calculate the marginal tax rate (or the perfect-foresight marginal tax rate) based on either the tax returns $(M T R / P M T R)$ or the financial statements $\left(M T R^{F S} / P M T R^{F S}\right)$. The dependant variable is $\triangle L e v_{i, t}$. In all these difference GMM estimations, we include the third and the fourth lags of leverage ratio, corresponding marginal tax rate and other control variables in the set of instruments. Columns 1-4 report estimation results based on the positive-profit-only sample. In Column 1 (or 2), we instrument the first-difference of $M T R_{i, t}$ (or that of $M T R_{i, t}^{F S}$ ) by the third and the fourth lags of the $M T R$ (or $M T R^{F S}$ ), and lags of profitability, tangibility, and firm size. In Column 3 (or 4), we instrument the first-difference of $M T R_{i, t}$ (or $M T R_{i, t}^{F S}$ ) by the third and the fourth lags of the beforefinancing $M T R$ (or $M T R^{F S}$ ), and lags of other control variables. For the full sample, in addition to the $M T R$ (Columns 5-6), we also use the perfect-foresight marginal tax rate as the measure for tax incentives based on the tax returns (PMTR) and based on financial statements $\left(P M T R^{F S}\right)$, separately in Columns 7 and 8 . Year dummies are included in all columns. We control for company-specific fixed effects by first-differencing Equation (7). Short-run dynamics are included in each column but not reported. Firm-level control variables are included. Standard errors are reported in parentheses, and are robust and clustered by firms. ${ }^{* * *} \mathrm{p}<0.01,{ }^{* *} \mathrm{p}<0.05,{ }^{*} \mathrm{p}<0.1$. 
Table 10: Marginal versus average effective tax rate

\begin{tabular}{|c|c|c|c|c|c|}
\hline Dep. Var: $\triangle L e v_{i, t}$ & (1)GMM & (2)GMM & (3) GMM & $\begin{array}{c}\text { Excluding bunchers } \\
\text { at £300k } \\
\text { (4) GMM }\end{array}$ & $\begin{array}{l}\text { Excluding bunchers } \\
\text { at } £ 10 \mathrm{k} \text { and } £ 300 \mathrm{k} \\
\text { (5) GMM }\end{array}$ \\
\hline $\operatorname{Lev}_{i, t-1}$ & $\begin{array}{c}-0.238^{* * *} \\
(0.034)\end{array}$ & $\begin{array}{c}-0.234^{* * *} \\
(0.034)\end{array}$ & $\begin{array}{c}-0.239^{* * *} \\
(0.033)\end{array}$ & $\begin{array}{c}-0.242^{* * *} \\
(0.032)\end{array}$ & $\begin{array}{c}-0.246^{* * *} \\
(0.033)\end{array}$ \\
\hline$M T R_{i, t-1}$ & $\begin{array}{c}0.182^{* *} \\
(0.083)\end{array}$ & & $\begin{array}{c}0.198^{* *} \\
(0.092)\end{array}$ & $\begin{array}{c}0.176^{* *} \\
(0.083)\end{array}$ & $\begin{array}{c}0.182^{* *} \\
(0.087)\end{array}$ \\
\hline$A E T R_{i, t-1}$ & & $\begin{array}{c}0.046 \\
(0.086)\end{array}$ & $\begin{array}{l}-0.006 \\
(0.040)\end{array}$ & $\begin{array}{l}0.085 \\
(0.174)\end{array}$ & $\begin{array}{c}0.005 \\
(0.038)\end{array}$ \\
\hline$\triangle M T R_{i, t}$ & $\begin{array}{l}0.203^{*} \\
(0.116)\end{array}$ & & $\begin{array}{l}0.213^{*} \\
(0.112)\end{array}$ & $\begin{array}{l}0.198^{*} \\
(0.112)\end{array}$ & $\begin{array}{c}0.174 \\
(0.115)\end{array}$ \\
\hline$\triangle A E T R_{i, t}$ & & $\begin{array}{c}0.027 \\
(0.048)\end{array}$ & $\begin{array}{c}-0.006 \\
(0.020) \\
\end{array}$ & $\begin{array}{c}0.006 \\
(0.021) \\
\end{array}$ & $\begin{array}{l}-0.002 \\
(0.019) \\
\end{array}$ \\
\hline Long-run coefficients & & & & & \\
\hline$M T R$ & $\begin{array}{c}0.764^{* *} \\
(0.379)\end{array}$ & & $\begin{array}{c}0.832^{* *} \\
(0.406)\end{array}$ & $\begin{array}{c}0.729^{* *} \\
(0.363)\end{array}$ & $\begin{array}{l}0.739^{* *} \\
(0.374)\end{array}$ \\
\hline AETR & & $\begin{array}{c}0.196 \\
(0.375)\end{array}$ & $\begin{array}{l}-0.024 \\
(0.169)\end{array}$ & $\begin{array}{c}0.085 \\
(0.174)\end{array}$ & $\begin{array}{c}0.020 \\
(0.153)\end{array}$ \\
\hline Control variables & Yes & Yes & Yes & Yes & Yes \\
\hline Year dummies & Yes & Yes & Yes & Yes & Yes \\
\hline Company FE & Yes & Yes & Yes & Yes & Yes \\
\hline Hansen test & 0.754 & 0.727 & 0.874 & 0.463 & 0.411 \\
\hline No. of groups & 9,439 & 9,439 & 9,439 & 9,317 & 9,199 \\
\hline No. of obs. & 32,173 & 32,173 & 32,173 & 30,908 & 30,185 \\
\hline
\end{tabular}

Notes: AETR is the average effective tax rate. We include the third and the fourth lags of all the explanatory variables in each specification in the set of instruments for the difference GMM estimations. We use lags of the $M T R$ and lags of other control variables as the instruments. We compute the long-run coefficients on the after-financing marginal tax rate and the average effective tax rate. Short-run dynamics are included in each column but not reported. Firm-level control variables are included. In Columns 1-3, we estimate based on the positive-profit-only sample. In Column 4, we exclude observations just below the $£ 300,000$ threshold. In Column 5, we exclude observations just below the $£ 300,000$ and $£ 310,000$ thresholds. Standard errors are reported in parentheses, and are robust and clustered by firms. ${ }^{* * *} \mathrm{p}<0.01,{ }^{* *} \mathrm{p}<0.05,{ }^{*} \mathrm{p}<0.1$. 
Appendix A: Statutory Marginal Tax Rates and Tax Brackets: 2001-2009

\begin{tabular}{|c|c|c|c|c|c|}
\hline Taxable profits & $2001 / 2002$ & $\begin{array}{l}2002 / 2003- \\
2005 / 2006\end{array}$ & $2006 / 2007$ & $2007 / 2008$ & $\begin{array}{l}2008 / 2009- \\
2009 / 2010\end{array}$ \\
\hline $0-10,000$ & $10 \%$ & $0 \%$ & $19 \%$ & $20 \%$ & $21 \%$ \\
\hline $10,001-50,000$ & $22.5 \%$ & $23.75 \%$ & $19 \%$ & $20 \%$ & $21 \%$ \\
\hline $50,001-300,000$ & $20 \%$ & $19 \%$ & $19 \%$ & $20 \%$ & $21 \%$ \\
\hline $300,001-1,500,000$ & $32.5 \%$ & $32.75 \%$ & $32.75 \%$ & $32.5 \%$ & $29.75 \%$ \\
\hline$>1,500,000$ & $30 \%$ & $30 \%$ & $30 \%$ & $30 \%$ & $28 \%$ \\
\hline
\end{tabular}

Notes: This table displays the statutory marginal corporate income tax rates and the corresponding tax bracket for UK companies during the fiscal years 2001-2009.

\section{Appendix B: Definition of variables}

Taxable income in tax returns: box 37 in CT600, which reports companies' actual taxable income after deducting interest expenses.

Estimated taxable income in financial statement: we estimate companies' taxable income using financial statements by adding tax expenses to net income, which includes minority interest.

Statutory after-financing marginal tax rate $(M T R)$ : this is calculated based on companies' taxable income (either reported in tax returns or estimated based on financial statements, the latter is labelled as $M T R^{A}$ after deducting interest expenses. For loss-making companies, this measure equals to zero.

Statutory before-financing marginal tax rate $\left(M T R_{b e f o r e}\right)$ : this is calculated based on companies' taxable income (either reported in tax returns or estimated based on financial statements, the latter is labelled as $M T R_{\text {before }}^{A}$ before deducting interest expenses. If a firm's before-financing taxable profit is non-positive, this measure is set to be zero. The schedule of statutory corporate income tax rate in the UK during the fiscal years 2001/2002-2009/2010 is provided in Table A.

Perfect-foresight after-financing marginal tax rate $(P M T R)$ : To construct the perfect-foresight marginal tax rate, we make the following assumptions. If the company is in a loss-making position in year $t-1$ and year $t$, the company must carry forward its current taxable losses until year $t+s$ when taxable profit becomes positive for the first time. In this case, we set the effective marginal tax rate to be $M T R_{t+s} /(1+r)^{s}$, where $M T R_{t+s}$ is the statutory after-financing marginal tax rate the company would face in year $t+s$. The discount rate $r$ is set to be $7 \%$ which is the average interest rate for companies in our full sample. ${ }^{22}$ If the company is instead able to carry backward its taxable losses to year $t-1$, we assume that it takes time for the company to obtain tax refund from the tax authority and set the marginal tax rate to be $M T R_{t-1} /(1+r)$. We need to make strong assumptions to calculate the perfect-foresight marginal tax rate as we only

\footnotetext{
${ }^{22}$ We experimented with a discount rate of $5 \%$ or $2 \%$ and the results are not affected.
} 
observe up to 9 years for each company. If the company makes losses every year we assume its marginal tax rate to be zero. This is a stronger assumption when imposed on the first and the last observations for each company. If the company makes a loss in the first year, we do not know whether the company can carry backward the current losses. If the last observation is in a loss-making position, we do not know whether the company carries forward its losses or not. As a result, there may be larger measurement errors in these cases. This is the rationale to omit the first and the last observations as a robustness check in our estimations. The corresponding measure based on financial statements is labelled as $P M T R^{A}$.

Leverage ratio $(L e v)$ : this is defined as $(L T D+S T D) /(L T D+S T D+B E)$, where $L T D$ is long-term debt, $S T D$ is short-term debt, and BE is the value of the company's book equity, all of which are obtained from companies' balance sheets provided by FAME.

Average effective tax rate $(A E T R)$ : this is defined as the ratio between gross corporate income tax paid and taxable income. Both the numerator and the denominator are obtained from the tax returns.

External leverage ratio (EXLev): this is constructed as (External debt)/(Total debt). Total debt is the sum of internal and external debt, both reported in FAME.

Profitability: this is the ratio of net income (profits/loss for the period) to total assets. Both the numerator and the denominator are obtained from FAME.

Tangibility: this is the ratio of tangible fixed assets to total assets. Both the numerator and the denominator are obtained from FAME.

Size: this is proxied as the logarithm of companies' total assets. 


\section{Appendix C \\ Table C1: Summary Statistics of Key Variables for Domestic Stand-alone firms and Multinational Companies}

Panel A: Positive-profit-only sample

\begin{tabular}{|c|c|c|c|c|c|c|c|}
\hline \multicolumn{8}{|l|}{ Domestic stand-alone } \\
\hline & Mean & S.D. & p25 & p50 & \multicolumn{2}{|c|}{ p75 } & No. ob \\
\hline Taxable profits & 290,360 & 948,854 & 28,391 & 93,775 & \multicolumn{2}{|c|}{279,522} & 34,64 \\
\hline Size & 14.124 & 1.557 & 12.934 & 14.289 & \multicolumn{2}{|c|}{15.272} & 34,64 \\
\hline Tangibility & 0.461 & 0.328 & 0.163 & 0.394 & \multicolumn{2}{|c|}{0.774} & 34,64 \\
\hline Profitability & 0.092 & 0.114 & 0.026 & 0.056 & \multicolumn{2}{|c|}{0.115} & 34,64 \\
\hline Total leverage & 0.470 & 0.264 & 0.253 & 0.453 & \multicolumn{2}{|c|}{0.675} & 34,64 \\
\hline Internal leverage ratio & 0.050 & 0.110 & 0.000 & 0.000 & \multicolumn{2}{|c|}{0.000} & 34,64 \\
\hline \multicolumn{8}{|c|}{ Companies belonging to a multinational group } \\
\hline Taxable profits & $1,227,098$ & $4,134,946$ & 109,937 & 318,880 & \multicolumn{2}{|c|}{850,636} & 13,58 \\
\hline Size & 15.608 & 1.358 & 14.861 & 15.506 & \multicolumn{2}{|c|}{16.303} & 13,58 \\
\hline Tangibility & 0.350 & 0.285 & 0.111 & 0.270 & \multicolumn{2}{|c|}{0.522} & 13,58 \\
\hline Profitability & 0.073 & 1.358 & 0.026 & 0.055 & \multicolumn{2}{|c|}{0.098} & 13,58 \\
\hline Total leverage & 0.440 & 0.285 & 0.232 & 0.422 & \multicolumn{2}{|c|}{0.633} & 13,58 \\
\hline Internal leverage ratio & 0.142 & 0.222 & 0.000 & 0.013 & \multicolumn{2}{|c|}{0.213} & 13,58 \\
\hline \multicolumn{8}{|l|}{ Panel B: Full sample } \\
\hline Domestic stand-alone & & & & & & & \\
\hline & Mean & S.D. & $\mathrm{p} 25$ & $\mathrm{p} 50$ & $\mathrm{p} 75$ & No. & obs. \\
\hline Taxable profits & 194,761 & 781,047 & 0.000 & 34,094 & 161,268 & & 978 \\
\hline Size & 14.245 & 1.566 & 13.069 & 14.432 & 15.351 & & 978 \\
\hline Tangibility & 0.476 & 0.325 & 0.178 & 0.430 & 0.784 & & 978 \\
\hline Profitability & 0.061 & 0.109 & 0.008 & 0.037 & 0.087 & & 978 \\
\hline Total leverage & 0.502 & 0.264 & 0.291 & 0.497 & 0.715 & & 978 \\
\hline Internal leverage ratio & 0.050 & 0.142 & 0.000 & 0.000 & 0.000 & & 978 \\
\hline Companies belonging t & a multina & itional group & & & & & \\
\hline Taxable profits & 724,163 & $3,099,718$ & 0.000 & 77,150 & 441,502 & & 214 \\
\hline Size & 15.763 & 1.427 & 14.904 & 15.634 & 16.524 & & 214 \\
\hline Tangibility & 0.369 & 0.292 & 0.117 & 0.299 & 0.565 & & 214 \\
\hline Profitability & 0.048 & 0.083 & 0.008 & 0.036 & 0.079 & & 214 \\
\hline Total leverage & 0.496 & 0.262 & 0.286 & 0.494 & 0.705 & &, 214 \\
\hline Internal leverage ratio & 0.190 & 0.257 & 0.000 & 0.048 & 0.328 & & 214 \\
\hline
\end{tabular}


Table C2: Number of Tax Changes within Companies, by ownership Positive-profit-only sample: Total number of moving in and out of the $£ 300,000$ tax bracket

\begin{tabular}{|c|c|c|c|c|}
\hline \multicolumn{5}{|c|}{ Multinational companies } \\
\hline No. of changes & No. of companies & $\%$ total companies & No. of obs. & $\%$ total obs. \\
\hline 0 & 1,273 & $51.79 \%$ & 6,750 & $49.69 \%$ \\
\hline 1 & 578 & $23.52 \%$ & 3,111 & $22.90 \%$ \\
\hline 2 & 384 & $15.62 \%$ & 2,160 & $15.90 \%$ \\
\hline$\geqq 3$ & 223 & $9.08 \%$ & 1,564 & $11.51 \%$ \\
\hline Total & 2,458 & $100 \%$ & 13,585 & $100 \%$ \\
\hline \multicolumn{5}{|c|}{ Domestic companies } \\
\hline No. of changes & No. of companies & $\%$ total companies & No. of obs. & $\%$ total obs. \\
\hline 0 & 4,894 & $70.1 \%$ & 25,251 & $67.40 \%$ \\
\hline 1 & 928 & $13.29 \%$ & 5,062 & $13.51 \%$ \\
\hline 2 & 761 & $10.90 \%$ & 4,348 & $11.61 \%$ \\
\hline$\geqq 3$ & 549 & $5.70 \%$ & 2,805 & $7.00 \%$ \\
\hline Total & 6,981 & $100 \%$ & 37,466 & $100 \%$ \\
\hline \multicolumn{5}{|c|}{ Full sample: Total number of moving in and out of losses } \\
\hline \multicolumn{5}{|c|}{$\begin{array}{ll}\text { Multinational companies } \\
\end{array}$} \\
\hline No. of changes & No. of companies & $\%$ total companies & No. of obs. & $\%$ total obs. \\
\hline 0 & 2,155 & $46.88 \%$ & 12,081 & $44.08 \%$ \\
\hline 1 & 1,185 & $25.78 \%$ & 6,817 & $24.87 \%$ \\
\hline 2 & 803 & $17.47 \%$ & 5,106 & $18.63 \%$ \\
\hline$\geqq 3$ & 454 & $9.87 \%$ & 3,404 & $12.42 \%$ \\
\hline Total & 4,597 & $100 \%$ & 27,408 & $100 \%$ \\
\hline \multicolumn{5}{|c|}{ Domestic companies } \\
\hline No. of changes & No. of companies & $\%$ total companies & No. of obs. & $\%$ total obs. \\
\hline 0 & 5,908 & $51.25 \%$ & 31,960 & $48.53 \%$ \\
\hline 1 & 2,792 & $24.22 \%$ & 15,597 & $23.69 \%$ \\
\hline 2 & 1,897 & $16.46 \%$ & 11,599 & $17.61 \%$ \\
\hline$\geqq 3$ & 930 & $8.07 \%$ & 6,695 & $10.17 \%$ \\
\hline Total & 11,527 & $100 \%$ & 65,851 & $100 \%$ \\
\hline
\end{tabular}

